\title{
A severe hail storm in complex topography in Switzerland - observations and processes
}

Simona Trefalt ${ }^{\mathrm{a}, \mathrm{b}, \mathrm{c}, \mathrm{d}, *}$, Andrey Martynov ${ }^{\mathrm{b}, \mathrm{c}}$, Hélène Barras ${ }^{\mathrm{b}, \mathrm{c}, \mathrm{e}}$, Nikola Besic ${ }^{\mathrm{f}, \mathrm{d}}$, Alessandro M. Hering ${ }^{\mathrm{d}}$, Sina Lenggenhager ${ }^{\mathrm{b}, \mathrm{c}}$, Pascal Noti ${ }^{\mathrm{e}}$, Matthias Röthlisberger ${ }^{\mathrm{b}, \mathrm{c}}$, Sebastian Schemm ${ }^{\mathrm{g}}$, Urs Germann ${ }^{\mathrm{d}}$, Olivia Martius $^{\mathrm{a}, \mathrm{b}, \mathrm{c}}$

\author{
${ }^{a}$ Mobiliar Lab for Natural Risks, University of Bern, Bern, Switzerland \\ ${ }^{b}$ Oeschger Centre for Climate Change Research, University of Bern, Bern, Switzerland \\ ${ }^{c}$ Institute of Geography, University of Bern, Bern, Switzerland \\ ${ }^{d}$ Division for Radar, Satellite and Nowcasting, MeteoSwiss, Locarno Monti, Switzerland \\ ${ }^{e}$ Division for Analysis and Forecasting, MeteoSwiss, Zurich Airport, Switzerland \\ ${ }^{f}$ Environmental Remote Sensing Laboratory, EPFL, Lausanne, Switzerland \\ ${ }^{g}$ Geophysical Institute and Bjerknes Centre for Climate Research, University of Bergen, Bergen, Norway
}

\begin{abstract}
This paper studies a damaging hail storm that occurred on 6 June 2015 in the complex topography of Switzerland. The storm persisted for several hours and produced large hail resulting in significant damage. Storms of comparable severity occur on average only three times per year within the entire Swiss radar domain, but are rare events at this exact location, according to a set of over 400,000 automatically identified storms. A multitude of datasets, partly novel for central Europe, is now available to study the storm in great detail capturing its impacts, severity and development. The data we use include radar-based hail products, crowd-sourced hail reports, and insurance loss data. These independent datasets permitted a verification of both hail occurrence and hail size estimations by radar. The crowd-sourced reports agree well with radar-based hail observations and insurance data. Model data (ERA-Interim reanalysis, regional COSMO2 analysis and WRF simulations) and radio-sounding data showed, that conditions were favourable for thunderstorm development due to an unstable and moist atmosphere over Switzerland, brought about by an interplay of large-scale pattern and local processes. Advection ahead of a cold front west of Switzerland and local evapotranspiration lead to high lower-tropospheric moisture. The large-scale flow and topographically induced Alpine pumping resulted in strong directional wind shear, and contributed to the longevity and severity of this storm. The cold front was not relevant for the vertical lifting. Using model simulations with very high resolution, we identified mountain wind systems and cold-air outflow as possible triggering and propagation mechanisms of this hail storm.
\end{abstract}

Keywords: hail, weather radar, crowd-sourcing, severe weather, complex topography, WRF

\footnotetext{
* Corresponding author

Email addresses: simona.trefalt@meteoswiss.ch (Simona Trefalt), andrey.martynov@giub.unibe.ch (Andrey Martynov), olivia.romppainen@giub.unibe.ch (Olivia Martius) 


\section{Introduction}

Hail is among the costliest natural hazards in Switzerland and causes considerable damage to agriculture, cars and buildings almost on a yearly basis (VKF, 2013, BAFU, 2016). According to radar observations, hail occurs on average once per convective season per $\mathrm{km}^{2}$ in large areas of Switzerland with the exception 5 of the inner Alpine valleys. It occurs more than twice per convective season per $\mathrm{km}^{2}$ in the hail hot spots in southern Switzerland, the Jura mountains, and along the northern central Prealps (Nisi et al., 2016; Bider. 1954). Large hail, i.e., hail stones with a diameter $\geq 3 \mathrm{~cm}$, are observed approximately every five years in the area studied in this paper (Nisi et al., 2016).

In Switzerland, no continuous, systematic, direct ground observations of hail are available that cover the entire territory. Hence, long-term information on hail occurrence and its size is either based on radar information (Willemse, 1995, Nisi et al., 2016) or derived from insurance damage claims (e.g., Bider, 1954 , Willemse, 1995). Both of these data sources provide indirect information on hail and rely on direct observations for initial calibration and verification. In the past, data from dedicated field campaigns have been used for this purpose (Federer et al. 1978, Smith \& Waldvogel, 1989). In recent years, radar technology has substantially improved, resulting in new dual-polarisation hail detection algorithms developed for the Swiss radar network (Besic et al., 2016), that might, after a comprehensive verification, be employed for calibration and validation of other indirect observation. Additionally, a growing number of direct crowd-sourced hail observations have recently become available. This includes observer reports from the European Severe Weather Database (ESWD, Dotzek et al., 2009, Groenemeijer et al., 2017) and data collected with reporting functions in mobile applications (Apps) such as the MeteoSwiss App ${ }^{1}$, the EWOB Apq ${ }^{2}$ or the mPING App (Elmore et al., 2014).

In this study, we use these crowd-sourced hail datasets in combination with high-resolution radar-based hail products and numerical weather prediction model output to analyse a hail storm in Switzerland that occurred on 6 June 2015. This hail storm, referred to as the 'Thun storm' throughout this article, affected the densely populated area of the Aare and Guerbe valleys (cf., Fig. 19). It produced large hail stones ( $\geq 3$ $\mathrm{cm}$ ) and resulted in significant damage. This hail storm was long-lived: It was observed by radar for 135 minutes, while covering a distance of about $50 \mathrm{~km}$. This longevity combined with its path over a densely populated area contributed to its high impacts.

In this study, we are also interested in the processes and mechanisms that lead to the formation and propagation of the 'Thun storm' in the complex terrain of the northern Swiss Prealps (cf., Fig. 11). Such complex

\footnotetext{
${ }^{1}$ More information here: http://www.meteoswiss.admin.ch/home/services-and-publications/advice-and-service/ meteoswiss-app.html, last access 14 December 2017

${ }^{2}$ More information here: https://www.essl.org/cms/european-severe-weather-database/ewob/ last access 14 December 2017
} 
topography can play a major role in modulating convective events, e.g., via thermo-topographic wind systems that trigger convective cells (e.g., Banta, 1990, Barthlott et al., 2011) or by geographically anchoring heavy rainfall (e.g., Caracena et al. 1979; Banta, 1990, Rotunno \& Ferretti, 2001; Rudari et al., 2004, Rotunno \& Houze, 2007, Kottmeier et al., 2008, Hagen et al., 2011; Houze, 2012, Gascón et al., 2016). Moreover, the

35 climatological distribution of hail storm formation in Switzerland, with the aforementioned hail frequency maxima over complex topography (Nisi et al. 2016), also points to a strong orographic influence on hail occurrence. However, detailed process studies on the role of the orography for hail are mostly missing for Switzerland.

Generally, an environment that is conducive to the formation of deep moist convection and hail, irrespective

40 of the presence of complex topography, is characterised by abundant lower-tropospheric moisture, an unstable atmosphere, and a storm trigger, i.e., a lifting mechanism, which is needed to release the instability (e.g., in general and for a specific region, Johns \& Doswell III, 1992, Gascón et al., 2015). As a fourth factor, vertical wind shear can influence the lifetime of storms. Wind shear is needed for the formation of multicell storms, as it assists the spatial separation of up- and downdraft regions (e.g., Rotunno et al., 1988, Bluestein, 1993: Davies \& Johns, 1993, Doswell III \& Evans, 2003. Markowski \& Richardson, 2010). Increasing the lifetime of a storm, together with strong vertical winds, increases the time that a hail stone can grow before it precipitates, and is central for the formation of large hail. Environments prone to severe convection in Europe slightly differ from those in North America (e.g., Brooks, 2009). Values of Convective Available Potential Energy (CAPE) associated with severe convection in Europe are typically much lower compared to 50 the US (e.g., Brooks, 2009). Large hail in Europe is usually observed in environments characterised by high boundary layer moisture, a high lifting condensation level and steep lapse rates (Taszarek et al., 2017), and by combinations of high-CAPE moderate-shear or moderate-CAPE high-shear environments (e.g., Craven \& Brooks, 2004; Groenemeijer \& van Delden, 2007, Kaltenböck et al., 2009, Pućik et al., 2015).

Such favourable conditions for hail occurrence are generally set up by the large-scale flow (e.g., García55 Ortega et al. 2014). In Switzerland, 30 to $40 \%$ of all hail storms form in pre-frontal environments (Schemm et al. 2016). Fronts can also erode capping inversions (e.g., Markowski \& Richardson, 2010), which inhibits the formation of storms, and can contribute to the vertical wind shear (Schemm et al. 2016). Advection of moist air ahead of cold fronts (Doswell III 1987) is also a well known low-level moisture source. In addition, (local) evapotranspiration can too act as important low-level moisture source for extreme precipitation associated with mesoscale convective systems (e.g., Martius et al. 2013) or moist convection in general (e.g., Findell \& Eltahir, 1997, Eltahir \& Bras, 1996). Soil moisture, further, controls the partitioning of the energy fluxes into latent and sensible fluxes, and thereby determines the moisture and temperature distribution of the planetary boundary layer (Ek \& Holtslag, 2004) and affects local-scale circulations (e.g., Guillod et al., 2015; Froidevaux et al., 2014). Moreover, several studies have highlighted important interactions between 65 complex orography and the synoptic flow for the development of severe weather, including hail (e.g., Giaiotti 
et al. 2003, Kaltenböck, 2004; Kunz \& Puskeiler, 2010). For example, in Austria, severe convection often develops ahead of a slow-moving cold front approaching from the west, with convergence lines forming ahead of the front, and with strong solar radiation responsible for warm anomalies on hilly terrain and southern mountain slopes (Kaltenböck, 2004). Furthermore, Kunz et al. (2017) showed the role that orography played in the development of a supercell, which affected southern Germany, related to the local invigoration of wind shear.

While the environment and storm characteristics of several hailstorms in Switzerland have been studied in e.g.; Houze et al. (1993), until now, only few process-oriented case studies of severe convective storms exist: Schmid et al. (1997) reported on three supercell storms, and Schmid et al. (2000) and Peyraud (2013) on two

distinct tornadic storms. Here, we aim at filling this gap by making use of novel (radar-based, model-based, and crowd-sourced) datasets that have become available in recent years, which allowed us to study the hail storm of 6 June 2015 in greater detail, and to put it in a climatological perspective.

Specifically, the aims of the paper are to describe:

1. the hail storm impacts by using crowd-sourced data and to compare this data with radar-based hail products,

2. the role of the large-scale flow and the cold front for the hail storm formation,

3. the sources of low-level moisture and to quantify them,

4. the role of the orography for the local atmospheric environment and the triggering and propagation of the hail storm.

\section{Data and methods}

\subsection{Crowd-sourced hail reports, insurance claims and independent observations}

In May 2015, a hail reporting function was added to the MeteoSwiss mobile App. With almost 3.4 million downloads by the end of June 2015 (Aebischer, MeteoSwiss, 2016, personal communication), the App was accessible to a large fraction of the Swiss population (about 8.2 million as of $2015^{3}$ ) on the day of the hail storm, although the number of active users on that day is not known. In June 2015, the App allowed users to report hail observations in four different hail size classes (see Table 1. classes increased to six in early autumn 2017) or 'no hail'. The time and GPS location of the mobile device are automatically added to the report, but may be adapted by the user if they report a posteriori. Here, all hail reports were matched spatially and temporally against the Probability of Hail ( $\mathrm{POH}$ ) radar product (see next Section). Reports are verified if they are within $4 \mathrm{~km}$ from the nearest $\mathrm{POH} \geq 60 \%$ signal, a threshold derived from

\footnotetext{
${ }^{3}$ Source: Swiss Federal Statistical Office, https://www.bfs.admin.ch/bfs/en/home/statistics/population.html, last access 14 December 2017
} 
sensitivity studies, which accounts for possible wind drift of hail stones and the users' displacement from the hail location. Furthermore, a temporal shift between the hail reports and POH signal is allowed, and reports are kept, if $\mathrm{POH} \geq 60 \%$ is observed within a 40 min window centered on the time of the hail report. This short time interval is chosen to guarantee high quality reports. Of 680 submitted hail size reports on 6 June 2015 for entire Switzerland (excluding submitted 'no hail' reports, see Table 1), 289 reports (42.5 \%) fulfilled the strict spatial and temporal matching criteria. This is a typical fraction of the total submitted reports.

The Swiss Mobiliar Insurance company, further, provided daily claim numbers for hail damages to cars, spatially aggregated to the level of the Swiss postcodes (3186 as of 2016 with a mean size of less than $10 \mathrm{~km}^{2}$ ). Damage to cars is expected with hail diameters $\geq 2.5 \mathrm{~cm}$ (VKF, 2007), but also depends on the intensity and shape of the hail stones. Insurance data entails some uncertainty since a wrong damage location might be reported, or the exact damage location might be unknown due to the car owners driving when the damage occurred (see Morel, 2014, for a thorough discussion of error sources). In addition to hail damages to cars, text, photo and video material with approximate geographic information was available online documenting the major storm of 6 June 2015. Six of these online reports were verified and added to the ESWD (Dotzek et al., 2009); three of them state a hail diameter and were considered in this paper. No reports for the area of interest were available from the mPING database (Elmore et al., 2014).

\subsection{Radar-based precipitation, hail, thunderstorm, and hydrometeor classification datasets}

To describe the precipitation patterns and convective hot spots, we used radar-based precipitation fields from MeteoSwiss. This data is available every $5 \mathrm{~min}$, i.e. after each full volume scan, with $1 \mathrm{~km}$ horizontal resolution. Information on the Swiss radar network and its five dual-polarisation Doppler C-band radars, of which four were operational as of 6 June 2015, can be found in Germann et al. (2015), Germann et al. (2016) and Willemse \& Furger (2016).

\subsection{1. $P O H$ and MESHS}

The $\mathrm{POH}$, which indicates the probability of hail reaching the ground, is computed operationally at MeteoSwiss following Waldvogel et al. (1979) and Foote et al. (2005). It is an empirical relation based on the difference in height $(\Delta \mathrm{z})$ between the altitude of the centre of the highest radar bin at which a $45 \mathrm{dBZ}$ echo is found, i.e., the EchoTop of $45 \mathrm{dBZ}$ (henceforth ET45), and the height of the freezing level $\left(\mathrm{H}_{0}\right)$ retrieved from the forecasts of the numerical weather prediction model COSMO-2 (see Section 2.3). For $\Delta \mathrm{z}$ $<1.65 \mathrm{~km} \mathrm{POH}$ is $0 \%$, while with $\Delta \mathrm{z} \geq 5.5 \mathrm{~km}$ it is $100 \%$. $\mathrm{POH}$ has been verified using insurance loss data (Morel, 2014, Nisi et al., 2016) and a good match was found between hail damage and POH $\geq 80 \%$

${ }^{4}$ Source: Swiss Federal Statistical Office, https://www.bfs.admin.ch/bfs/de/home/statistiken/regionalstatistik/ regionale-portraets-kennzahlen/gemeinden.assetdetail.2140839.html, last access 14 December 2017 
(probability of detection 0.9, false alarm rate 0.55 and a critical success index of 0.45). Capozzi et al. (2018) most recently verified $\mathrm{POH}$ as defined here, but also versions considering the difference in height between ET35 or ET40 and $\mathrm{H}_{0}$ for the Naples Metropolitan region in Italy. For their study area, they identify a better performance using ET40 than ET45.

The Maximum Expected Severe Hail Size (MESHS) algorithm (Treloar, 1998; Joe et al., 2004) estimates the maximum expected diameter of hail at the ground for hail $\geq 2 \mathrm{~cm}$. The computation is based on an empirical relation of $\Delta \mathrm{z}$ between $\mathrm{H}_{0}$ and ET50, and the hail size observed at the ground. MESHS has been verified in Webb et al. (2001), Betschart \& Hering (2012) and Nisi et al. (2016). For Switzerland, it still lacks a more extensive verification with ground observations, such as those now available from crowd-sourcing.

\subsection{2. $T R T$}

Since 2004, MeteoSwiss has operationally run the Thunderstorms Radar Tracking (TRT) algorithm (Hering et al. 2004, Rotach et al. 2009). The algorithm tracks contiguous areas exceeding a dynamic reflectivity threshold (varying between 36 and $48 \mathrm{dBZ}$ ) and identifies individual thunderstorm cells and storm clusters. The identification of storm perimeters allows to analyse the storm track and the evolution of radar fields of individual storms. For every 5 min time step, storms are further heuristically classified into four severity classes: 'weak', 'moderate', 'severe' and 'very severe'. The four categories are based on the radar-derived Vertically Integrated Liquid Water Content (VIL), the median ET45 within the storm perimeter, the overall reflectivity maximum within the vertical columns (MaxEcho), and the storm area exceeding $57 \mathrm{dBZ}$ (see Hering et al., 2008, for more details).

\subsubsection{Hydrometeor classification}

The semi-supervised hydrometeor classification method of Besic et al. (2016) provides information on different hydrometeors, including hail. This method was applied to the dual-polarisation measurements of the Swiss radar network and is run operationally. The nine available hydrometeor classes are 'melting hail' ,'ice hail and high density graupel', 'wet snow', 'vertical ice', 'rimed part', 'rain', 'light rain', 'aggregates' and 'crystals', and only the first two are considered here. For more details see Besic et al. (2016).

\subsection{Analysis and reanalysis data and their applications}

The local analysis COSMO-2 (Consortium for Small-scale Modeling model operated by MeteoSwiss, Schättler et al. 2008) and the ECMWF global reanalysis ERA-Interim (Dee et al., 2011) were used in this study to characterise the local- and large-scale atmospheric conditions prior to and during the major hail event of 6 June 2015. The COSMO-2 model analysis, which was operational at MeteoSwiss from February 2008 to March 2016, was employed to characterise the local atmospheric situation in the hours before the convective activity. This data has a horizontal grid-spacing of $2.2 \mathrm{~km}, 60$ vertical levels and a time resolution of $1 \mathrm{~h}$ and uses a one-moment microphysics scheme. Data assimilation includes radar-based precipitation 
$\mathrm{h}$ temporal resolution, 60 vertical levels and all variables interpolated onto a $1^{\circ}$ by $1^{\circ}$ horizontal mesh-grid, was used to climatologically classify CAPE and precipitable water (PW) on 6 June 2015. The reanalysis data was, furthermore, employed to quantify the vertical motion by the large-scale flow. This was done by carrying out an inversion of the $Q$-vector formulation of the quasi-geostrophic (QG) Omega equation (Doswell III, 1987; Hoskins et al., 1978) by following the procedures of Clough et al. (1996) and Stone (1968). The $Q$-vectors were calculated every 6 h between 0000 UTC and 1800 UTC on 6 June 2015, and the inversion of the QG Omega equation was computed for all $25 \mathrm{hPa}$ intervals between $200 \mathrm{hPa}$ and $1000 \mathrm{hPa}$. Lastly, ERA-Interim reanalysis was used to identify moisture sources with three-day backward-trajectories of air masses. These were computed using the software tool LAGRANTO (Sprenger \& Wernli, 2015) applied to the 6-hourly reanalysis data. Trajectories were started from ten equidistant points north of the Swiss Alps from low- (800-900 hPa), mid- (450-550 hPa) and upper-levels (200-300 hPa).

\subsection{High-resolution WRF simulations}

The Weather Research and Forecasting Model (WRF) version 3.6.1 $5^{5}$ was used to investigate local-scale processes influencing convection. The model run with a similar horizontal grid-spacing as COSMO-2, i.e., $2.14 \mathrm{~km}$ x $1.35 \mathrm{~km}$, at which convective processes are explicit. However, the output fields have a much higher temporal resolution, namely $5 \mathrm{~min}$. A total of four (plus one control) simulations were run with different initialisation times and microphysics schemes. Three simulations (plus the control run) with starting times 0000 UTC on 25, 26 and 27 May 2015 were run with the Morrison double-moment scheme (Morrison et al. 2009, simulations M1, M2 and M3 henceforth). A further simulation, started at 0000 UTC on 25 May 2015 was run with the Thompson microphysics scheme (Thompson et al., 2008, simulation T1). ECMWF analysis was used as initial and 6-hourly updated boundary conditions. The WRF model was run along with the coupled 1D hail diagnostic model HAILCAST-1D (Brimelow et al. 2002, Adams-Selin \& Ziegler, 2016). In HAILCAST-1D, which is triggered by the updraft velocity exceeding a preset threshold, hail stone embryos are seeded to the clouds and evolve in a 1D vertical environment until they either disappear or fall to the ground. The mean size of hail stones on the ground is used as a measure of simulated hail storm size. Sensitivity experiments on the importance of orography for a hail storm simulation were carried out e.g., in García-Ortega et al. (2007), who found an adequate representation of the topography in their study area to be relevant for the correct simulation of a hail storm. Furthermore, Noppel et al. (2010) showed the effect of a change in cloud condensation nuclei and cloud drop size distributions on the simulation of a hail storm. These factors, however, remain unchanged in the simulations presented in this article.

${ }^{5}$ More information here: http://www2.mmm.ucar.edu/wrf/users/wrfv3.6/updates-3.6.1.html last access 14 December 2017 
Numerical simulations of hail storms at very high spatial resolution over limited spatial domains have been performed since the 1970s, using idealised cloud-resolving models (see Wu \& Li, 2008), mostly with the aim of studying the physical processes and/or dynamical effects in different convective environments, rather than reproducing observed events to study their initiation or propagation. More recently, the convection permitting modelling approach has been used to simulate single hail storms, typically at horizontal resolutions of 1 or 2 km (e.g., García-Ortega et al., 2007, Leslie et al., 2008; Mahoney et al., 2012, Chevuturi et al., 2014), as has been done for this study.

\subsection{Sounding data}

We used radio-sounding data from Payerne, Switzerland (06610 LSMP, 46 ${ }^{\circ} 48^{\prime}$ N, 6 ${ }^{\circ} 57^{\prime}$ E, $491 \mathrm{~m}$ a.s.l., see location in Fig. 1 1 ), available daily at 0000 UTC and 1200 UTC. These were retrieved from the University of Wyoming radio-sounding online archive

\section{Results and discussion}

\subsection{Hail areas, crowd-sourced hail reports and insurance loss data}

Small-scale local precipitation accumulation maxima (Fig. 2) and lightning data (not shown) for 6 June 2015 suggest that there was widespread convective activity. Radar hail products POH and MESHS show several areas with severe convection and locally large hail diameters (Fig. 3 a). For this day, hail size reports to the MeteoSwiss App are available from several parts of Switzerland. Of these hail size reports, 123 were filed from the Aare and Guerbe valleys (cfr., Fig. 1b), where the largest POH and MESHS areas and the highest MESHS values within Switzerland were estimated (Fig. 3b). Seventy-eight reports indicated 0.5-0.8 $\mathrm{cm}$ hail, 35 indicated hail corresponding to $2.3 \mathrm{~cm}$, and ten reports indicated large hail (six reports for hail with $3.1 \mathrm{~cm}$ diameter and four reports of even larger hail). All except seven of the 0.5-0.8 cm hail stone reports in this region were within the $\mathrm{POH} \geq 80 \%$ perimeter (Fig. $3 \mathrm{~b}$ ). Thirty-four out of 35 of the $2.3 \mathrm{~cm}$ hail stone size reports were within the minimum MESHS perimeter corresponding to $2 \mathrm{~cm}$ hail size. Except for one large hail report, namely a $\geq 3.1 \mathrm{~cm}$ hail size report, filed from outside the minimum $2 \mathrm{~cm}$ MESHS perimeter, all reports of large hail were located within the $3 \mathrm{~cm}$ MESHS perimeter. The remaining $\geq 3.1 \mathrm{~cm}$ hail size reports were, in fact, all within the $5 \mathrm{~cm}$ MESHS perimeter and close to the highest MESHS values in the region.

The areas affected by hail according to radar and crowd-sourced reports are densely populated. This explains, not only the relatively high number of crowd-sourced reports, but also the elevated number of car damage claims filed (see Fig. 3b). Swiss Mobiliar Insurance received a total of 1055 car damage claims for

\footnotetext{
${ }^{6}$ More information here: http://weather.uwyo.edu/upperair/sounding.html last access 14 December 2017
} 
6 June 2015 (Fig. 3b). All except two postcode areas with $\geq 5$ claims were located within the minimum MESHS perimeter of $2 \mathrm{~cm}$, where damages to cars can be expected. The postcode areas with $\geq 60$ claims were located in proximity of the highest MESHS values in the Aare and Guerbe valley (see $7 \mathrm{~cm}$ MESHS perimeter in Fig. 3b). Only few postcode areas with a single claim each were outside the $2 \mathrm{~cm}$ MESHS perimeter, which might be attributed to insurance data uncertainty.

ESWD verified reports, and photos published online or made available to us by private persons (see locations in Fig. $3 \mathrm{~b}$ and corresponding photos in Fig. 4 all additionally attest to the severe weather in the Aare and Guerbe valley, observed by radar and reported to the MeteoSwiss App by the local population. In this region, ESWD verified single hail diameters of $2 \mathrm{~cm}$ (Schwarzenegg), $3 \mathrm{~cm}$ (Niederscherli), and $5 \mathrm{~cm}$ (Muehlethurnen)

(Fig. 3b). The $2 \mathrm{~cm}$ hail stone (Schwarzenegg) verified by ESWD lies on the border of the $2 \mathrm{~cm}$ MESHS and $\geq 80 \%$ POH perimeters. At the location where ESWD verified $3 \mathrm{~cm}$ hail (Niederscherli), the MESHS product estimated $5 \mathrm{~cm}$ hail size. The largest hail stone verified by ESWD ( $5 \mathrm{~cm}$, Muehlethurnen) is in an area with $6 \mathrm{~cm}$ MESHS values. Photos show a considerable amount of hail of unknown size on the ground in the Stockhorn stadium in Thun and in Hilterfingen (Fig. 4 and Fig. 4 $\mathrm{d}$ ), both of which are within the $\geq 80 \% \mathrm{POH}$ perimeter (Fig. 3b). A picture of a $5 \mathrm{~cm}$ hail stone taken in Muelethurnen (Fig. 4b) and a photo with several hailstones of $4 \mathrm{~cm}$ diameter (Fig. 4 ) taken in Gerzensee validate the MESHS values nearby. We compared $\mathrm{POH}$ perimeters and hail reports to the hydrometeor classification and found good correspondence (Fig. 5). These comparisons showed, in addition to Nisi et al. (2016), that within a POH $\geq 80$ $\%$, it is indeed highly probable to have hail on the ground. For this case, the MESHS algorithm correctly identified the areas with largest hail sizes. The hail diameters themselves are larger in MESHS by about 1 $\mathrm{cm}$, which is plausible considering that the MESHS algorithm provides the largest expected hail size within a $1 \mathrm{~km}^{2}$ area, which may not always correspond to the hail stones documented by the reporters.

In summary, on 6 June 2015, direct and indirect ground observations indicate very large hail stones at the ground in the Aare and Guerbe valleys between the cities of Thun and Bern. The quality-controlled crowdsourced data gathered through the MeteoSwiss App and the car hail damage insurance claims corroborate the hail stone sizes estimated by radar. This shows that, in combination with radar data or other plausibilisation methods, the increasingly available crowd-sourced data provide very valuable information for research, such as previously demonstrated in Elmore et al. (2014) and Seimon et al. (2016) for the US. In the following sections we will analyse, first, the atmospheric conditions that lead to the convective activity of 6 June 2015 and, second, the radar-derived characteristics of the hail storm.

\subsection{Synoptic situation}

The large-scale pressure pattern over Europe at 1200 UTC on 5 June 2015, the day prior to the investigated hail storm, was characterised by a high pressure system located over central Europe and a low pressure system centred around $55^{\circ} \mathrm{N} 15^{\circ} \mathrm{W}$. A cold front extended from the British Isles in southwesterly 
direction across France and northern Spain (Fig. 6a). In the subsequent $24 \mathrm{~h}$, the cold front propagated eastward and was located just west of Switzerland and the Jura mountains at 1200 UTC on 6 June 2015 (Fig. 6p), where it became stationary during the following day.

At 1200 UTC on 5 June 2015, the upper-level flow was characterised by low potential vorticity (PV), i.e., an anticyclone, over central Europe, and by a high PV trough west of Ireland (Fig. 6.). By 1200 UTC on 6 June 2015 the anticyclone had propagated eastward with the centre then located over northeastern Europe. At this point, Switzerland was located at the western edge of the anticyclone.

The vertical wind field obtained by an inversion of the QG-omega equation allowed quantifying the largescale flow's and the front's influence on the observed vertical motion. Their contribution to the total vertical motion at 1200 UTC on 6 June 2015 was negligible at 700 and 500 hPa over Switzerland and over eastern France, where the front was located (not shown). This can be understood considering the very weak winds in the vicinity of the cold front over western Europe (Fig. 6).

\subsection{Pre-convective environment: Moisture, atmospheric stability and winds at different spatial scales}

While the front was not relevant in terms of vertical motion, it might have played a role in transporting moist air toward Switzerland. At 1200 UTC on 6 June 2015, air masses over northern Switzerland were very moist, reaching PW values between the $74^{\text {th }}$ and $96^{\text {th }}$ percentile $\left(20-27 \mathrm{~kg} \mathrm{~m}^{-2}\right)$ of the ERA-Interim 1200 UTC June climatology, with highest values in northeastern Switzerland. The Payerne radio-sounding (see sounding location in Fig. 17 and the skew-T diagram in Fig. 7) at 1200 UTC on 6 June 2015 measured PW amounting to $27 \mathrm{~kg} \mathrm{~m}^{-2}$, which corresponds to the $79^{\text {th }}$ percentile of the 1200 UTC June sounding statistics for 2008-2015. The sonde further measured a mean mixed layer mixing ratio of almost $12 \mathrm{~g} \mathrm{~kg}^{-1}$, which corresponds to the $96^{\text {th }}$ percentile of the same sounding statistics and indicates that especially the lower troposphere was very moist. According to three-day back-trajectories started at 1200 UTC on 6 June 2015, the air parcels of this moist lower tropospheric layer originated from the Ligurian sea in the southwest (Fig. 8a). Such low-level flow is consistent with the flow ahead of a cold front approaching Switzerland from the northwest or west (see cold front positions at 1200 UTC on 5 and 6 June 2015 in Fig. 6a and b). Some of the air parcels that reached Switzerland from the southwest already contained elevated levels of moisture three days prior to their arrival in Switzerland (Fig. 8f), but most of them then lost and regained moisture along their path (Fig. 8d). Between 0600 UTC and 1200 UTC on 6 June 2015, the low-level air parcels gained up to $3 \mathrm{~g} \mathrm{~kg}^{-1}$ of moisture (Fig. 8d), which corresponds to up to a third of their total moisture (Fig. 8c). According to the backwards-trajectories the low-level air parcels crossed the Jura mountains of Switzerland at that time, where it had abundantly rained the previous day (Fig. 9), before moving south toward the Alps (Fig. 8 a). Some of the moisture present in the lower-tropospheric air parcels at 1200 UTC on 6 June 2015 therefore stemmed from local sources.

The ERA-Interim CAPE values over northern Switzerland at 1200 UTC on 6 June 2015 were between the 
$86^{\text {th }}$ and $98^{\text {th }}$ percentile of the June climatology $\left(250-1,200 \mathrm{~J} \mathrm{~kg}^{-1}\right)$, and hence they were locally extreme (not shown). This is confirmed with the sounding statistics where a CAPE of 1,565 $\mathrm{J} \mathrm{kg}^{-1}$ (mixed-layer, lowest $500 \mathrm{hPa}$ ) was measured corresponding to the $99^{\text {th }}$ percentile of the 1200 UTC June sounding statistics for 2008-2015 (Fig. 7). The COSMO-2 analysis provides higher spatial detail of the moisture fields than the ERA-Interim reanalysis and provides information on the spatial representativeness of the Payerne radiosounding: At 1300 UTC on 6 June 2015 high-CAPE (most unstable, lowest $500 \mathrm{hPa}$ parcel) air masses were present in western Switzerland, and parts of the Swiss Plateau and the northern Prealps (Fig. 10a). The convective inhibition (CIN) of $92 \mathrm{~J} \mathrm{~kg}^{-1}$ measured by the radio-sounding corresponded to the $81^{\text {st }}$ percentile of the 1200 UTC June sounding statistics for 2008-2015. The COSMO-2 analysis revealed that CIN over the rest of Switzerland was generally below $40 \mathrm{~J} \mathrm{~kg}^{-1}$, reaching $100 \mathrm{~J} \mathrm{~kg}^{-1}$ only in the areas surrounding lakes, such as the area where the Payerne sounding was launched (Fig. 10 ). Two hours later at 1500 UTC, in the area where the first radar echoes of the hail storm were observed, CAPE reached values of 1500-1600 $\mathrm{J} \mathrm{kg}^{-1}$ in the COSMO-2 analysis (Fig. 10p). At the same time CIN had almost completely been depleted in this area $\left(\leq 10 \mathrm{~J} \mathrm{~kg}^{-1}\right.$, Fig. $\left.10 \mathrm{~d}\right)$.

As for single layers in the atmosphere at 1200 UTC on 6 June 2015, there was a deep, conditionally unstable layer between $900 \mathrm{hPa}$ and $640 \mathrm{hPa}$, a shallow stable layer between $640 \mathrm{hPa}$ and $600 \mathrm{hPa}$, and a conditionally unstable layer between $600 \mathrm{hPa}$ and $490 \mathrm{hPa}$, capped by a further shallow stable and very dry layer (Fig. 7). This dry layer in the mid-troposphere is identifiable also in the minimum $\Theta_{e}$ values at the location of Thun in the COSMO-2 analysis (not shown). This layer was captured by the backwards-trajectories started from the mid-troposphere, which showed that these air parcels reached Switzerland from the eastern Atlantic ocean after turning anticyclonically over central Europe (Fig. 8b). These mid-tropospheric air masses ascended during the $6 \mathrm{~h}$ prior to their arrival over northern Switzerland (Fig. 8 $\mathrm{d}$ ), while crossing the Alps. In the midday Payerne radio-sounding of 6 June 2015 the conditions for an elevated mixed layer, as defined in Banacos \& Ekster (2010), were not met.

The bulk vertical wind shear between low- and mid-level measured by the Payerne sonde at 1200 UTC on 6 June 2015 was moderate $\left(<10 \mathrm{~m} \mathrm{~s}^{-1}\right.$, Fig. 11). There was, however, a considerable difference in wind direction between the wind at low-levels (ground to $800 \mathrm{hPa}$ ) from north-northeast and the wind at midlevels from the south-southwest (600 hPa to $400 \mathrm{hPa}$, Fig. 11). The COSMO-2 analysis shows that the wind directions measured by the radio-sounding were representative for most of northern Switzerland: The 0-6 km bulk wind shear at 1300 UTC was moderate almost everywhere (generally $<12 \mathrm{~m} \mathrm{~s}^{-1}$, Fig. 12 ), and there was directional wind shear between low- and mid-levels of almost $180^{\circ}$ (Fig. 12. versus Fig. 12 ). The source of this directional shear were thermo-topographic winds. While a flow from southerly sectors was predominant at $500 \mathrm{hPa}$ throughout the first half of the day, the flow at $850 \mathrm{hPa}$ changed direction from southwesterly to northerly as the strength of the thermally driven orographic circulation between the Alps and its foreland, the so-called Alpine pumping (Hafner et al., 1987), increased during the morning. 
The directional wind shear remained strong in the Thun-Bern region shortly before the hail storm formed

325 (Fig. 12 versus Fig. 12).

In summary, the large-scale patterns over central Europe on the days prior and on 6 June 2015 resulted in the confluence of very moist air at low- and dry air at mid-tropospheric levels over Switzerland, causing an unstable atmosphere. In combination with weak CIN and directional wind shear, this contributed to an atmospheric environment favourable to the development of deep moist convection and large hail. It is, however, important to note that hail storms in northern Switzerland are not exclusively associated to extreme meteorological conditions (Trefalt, 2017).

\subsection{Radar-based classification of the Thun hail storm}

The damage in the Aare and Guerbe valleys was related to a single hail storm, referred to as the 'Thun storm', because it developed near and affected the city of Thun (see location in Fig. 19). In the early afternoon on 6 June 2015 several storms developed on the mountain peaks in the northern Prealps. First echoes related to this particular storm were seen on a mountain crest north of Lake Thun of approximately 2,000 m altitude at 1515 UTC. A storm was automatically identified by the TRT algorithm, and categorised according to its severity, shortly thereafter at 1525 UTC (Fig. 3b). The Thun storm remained quasistationary with very weak northwesterly propagation for approximately $1 \mathrm{~h}$ and then moved in northwesterly direction towards the city of Bern, following the Aare and the Guerbe river valleys (cf., Fig. 1a). The storm was tracked by radar until 1840 UTC, covering a distance of $49 \mathrm{~km}$ during its lifetime. In terms of severity, on the basis of radar-derived storm characteristics (Section 2.2), the Thun storm was classified by the TRT algorithm as 'severe' and 'very severe' for 55 min each. Maximum POH values inside the storm perimeter exceeded $80 \%$ for 2 h 20 min between 1550 UTC and 1810 UTC (Fig. 13a). During this time, there was a good match between the hydrometeor 'melting hail' class and the 5 min $80 \%$ POH perimeter (Fig. 5). The difference between the 'melting hail' class and the POH perimeter identifiable in Fig. 5 e is most probably due to a dying branch cell, which, despite not having null $\mathrm{POH}$, did not reach the $80 \%$ threshold. The storm-area median ET45, which approximately indicates the storm core height, remained above $6 \mathrm{~km}$ for a large fraction of the storm's lifetime (Fig. $13 \mathrm{~b}$ ). This is in good agreement with the range-height indicators (RHIs) of the hydrometeor classification (Fig. 5). Specifically, 'ice hail and high density graupel' were identified up to a height of $12 \mathrm{~km}$. The storm's area, i.e., the area within the storm perimeter detected by TRT, increased in the first $2 \mathrm{~h}$ to about $500 \mathrm{~km}^{2}$ and then more rapidly decreased until the storm dissipated (Fig. 13.). The Thun storm propagated rather slowly, with a velocity hardly exceeded $6 \mathrm{~m} \mathrm{~s}^{-1}$ (Fig. 13.). At 1700 UTC, the Thun storm reached its highest TRT severity ranking (rank 38, Fig. 13 a). Key radar characteristics contributing to the TRT severity classification at this time are summarised in Table 2 .

To objectively assess how extreme the Thun storm was, a large set of storms, automatically identified by the TRT algorithm within the entire Swiss radar domain during all seasons between mid-June 2012 and mid-June 
2016 were compared. From the detected 403,685 storms, only 1,019 (0.25\%) reached a duration comparable to that of the Thun storm. Only 12 storms (including the Thun storm), i.e., three storms per year, reached a 'very severe' ranking threshold for a minimum $55 \mathrm{~min}$, i.e., the same length as for the Thun storm. Of these storms, only the track of the centre of the Thun storm is entirely within Switzerland, while ten of the remaining storms occurred between Franche Compté in France and western Baden-Württemberg in Germany (cf., Fig. 17). These ten storms all had southwest-northeast oriented tracks, which are classically observed for thunderstorms off to the north from the Alpine chain during southwesterly flow situations (see e.g.; $(\sim 1 \mathrm{~h})$. All storms formed on mountain peaks (not shown) and some produced hail that reached the ground. A comparison of hail footprints from WRF simulations M1, M2, M3 and T1 within the area estimated as having had hail at the ground $(\mathrm{POH} \geq 80 \%)$ in reality during 6 June 2015 is shown in Fig. 15. While the modelled hail footprints deviate somewhat from reality and among the different simulations, this is to be Houze et al., 1993; Kunz et al., 2017). In contrast, the Thun storm had a rather meridionally oriented track (east-southeast to west-northwest; see track in Fig. 3b), due to the complex orography of the region where it developed and evolved (see Section 3.5 for a discussion on the importance of orography in this region). The propagation direction of the Thun storm is particular also if compared to a more representative 15-year dataset of hail cells that occurred within the Swiss radar domain (Nisi et al., 2018). Several radar-derived storm properties (TRT severity rank, maximum POH value within the storm perimeter, maximum of stormarea-median ET15, maximum of storm-area-median ET45, storm-area-maximum VIL, storm propagation velocity, storm area and mean storm propagation velocity) were compared between the Thun storm and the other 11 storms (Table 3), showing that considering these parameters the Thun storm is not the most extreme storm within the 12-storm subset. This subset of storms shows a high variability of mean velocity with a range from $4.5 \mathrm{~km} h^{-1}$ to $18.62 \mathrm{~km} h^{-1}$ and a standard deviation of $4.19 \mathrm{~km} h^{-1}$. The Thun storm had the second slowest mean propagation velocity of these storms. The statistical contextualisation shows that, within the Swiss radar domain, storms as severe as the Thun storm do not occur often (three per year). If the specific location of the Thun storm is taken into account, it is a rare event in a 4-year period.

\subsection{Triggering and propagation mechanisms in the northern Swiss Prealps}

To study the development of the Thun storm, we reverted to WRF simulations with a high temporal resolution (see Section 2.4). The WRF simulations, correctly reproduced the lower-tropospheric wind field associated with Alpine pumping, as a comparison of the WRF output with COSMO-2 model output and measurements of the ground weather stations of MeteoSwiss revealed (not shown). Both COSMO-2 and the four WRF simulations captured the precipitation structure well (Fig. 14). Focusing on the Thun storm, storms developed close to where the Thun storm formed in all WRF simulations, within a small time lag A comparison of hail footprints from WRF simations $\mathrm{M} 1, \mathrm{M} 2, \mathrm{M} 3$ and $\mathrm{T} 1 \mathrm{within}$ the area estimated as expected. The varying occurrence of hail at the ground might simply be attributed to the modelled storms and the observed Thun storm not having the same development, i.e., different tracks and lifetimes. Hence, 
updrafts of the storms were also not identical, which resulted in the hail at the ground to vary in the WRF simulations, because HAILCAST-1D depends on the vertical velocities within the thunderstorms.

Particularly the WRF M1 simulation has similar precipitation features to those observed by radar on 6 June 2015. In this simulation, a storm forms on a mountain peak north of Lake Thun at similar altitudes and only about $8 \mathrm{~km}$ southwest from where the first radar echoes of the Thun storm were observed ('M1 Thun storm' henceforth). It also has a comparable size and early-lifetime track. The M1 Thun storm developed about $1 \mathrm{~h}$ earlier compared to the observed Thun storm (Fig. 16a). At this time, above the top of the mountain, cloud water and cloud ice fields suggest a storm height of about $6 \mathrm{~km}$ (Fig. 17a), and ascending motions could be identified from the ground to the mid-troposphere (Fig. 17d). The air around the mountain peak was $\sim 1{ }^{\circ} \mathrm{C}$ warmer than the free atmosphere nearby (Fig. $17 \mathrm{k}$ ) and surface winds converged in the area of the thunderstorm (Fig. 163). This points to mountain wind systems creating the convergence and potentially triggering convection (Houze, 2012). Storms forming in an analogous manner on other mountain peaks of the Prealpine region were identified in all four WRF simulations.

At 1450 UTC, 30 min after the identification of the M1 Thun storm in the simulated MaxEcho field, the storm had further invigorated (Fig. 17p) and remained quasi-stationary (Fig. 16p). The air over the mountain peak was no longer warmer than the nearby free atmosphere (Fig. 17p). By 1520 UTC, the M1 Thun storm had grown taller (Fig. 17k) as the strength of the vertical motion had further increased (Fig. 17f). Between two columns of upward motion, a thin column of downward motion is identified just west of the mountain top (Fig. 17f), suggesting the presence of a downdraft. The air at the top of the mountain and along the western flank of the mountain was at this time up to $2^{\circ} \mathrm{C}$ colder than the nearby free atmosphere (Fig. 17k), which points to a cold pool at the surface that can move downslope. Winds along the western flank of the mountain towards lower elevations confirm this, and a new cell core can be identified at the bottom of the valley (Fig. 16 c). This suggests an auto-propagation mechanism of the storm: Because of the steep topography, the cold air, originating from the first cell, flowed downhill forming a gravity/density flow. Moving cold pools can accumulate moisture at the leading edge (e.g., Rotunno et al., 1988; Schlemmer \& Hohenegger, 2014) and contributed to vertical lifting.

The M1 Thun storm later propagated along the valley in northwesterly direction towards the Swiss Plateau, influenced by the mid-tropospheric southerly flow and the directional shear, a classical setting for multicell formation and propagation (Rotunno et al., 1988; Markowski \& Richardson, 2010). A new cell can be seen forming at the convergence between the outflow of the M1 Thun storm and the outflow of a second storm located on the western hills of the valley (Fig. 16 $\mathrm{d}$ ). The processes described above are based on the WRF simulations of the storm. While being plausible and in agreement with the few available direct observations of the Thun storm, they might not represent what happened in reality.

In all $4 \mathrm{WRF}$ simulations, the storm propagation in the Aare and Guerbe valley and other nearby Prealpine valleys was affected by other storms that formed on the mountain peaks on the sides of these valleys. Once 
the cells reach a mature stage and generate a cold air outflow, in the simulations, the cold air flows downslope into the Prealpine valleys. The details depend on the local topography, the exact thunderstorm location relative to the orography, and the outflow. In the valleys, these outflows then converge with the outflow from preexisting storms or with the northerly wind at low levels related to Alpine pumping. If strong enough, these convergences generate new thunderstorm cells, contributing to the storm propagation and longevity. The importance of low-level convergences and orography for severe convection, not only for storm initiation but also modification, was discussed also in case studies of other hail storms in central Europe and the UK, e.g., in Pedgley (2003), Clark (2011) and Kunz et al. (2017). Pedgley (2003) studied a storm on 7 May 2000 in Berkshire, United Kingdom associated with high precipitation intensity and long-lasting hailfall. In this case, a low-level convergence at the leading edges of sea-breezes and at the outflow boundary of a preexisting storm caused the storm to slow and the updraft to tilt forward. The tilting of the updraft temporally hindered the replacement of the updraft by downdrafts, which would have lead to a faster storm decay, and consequently allowed hail stones to grow in size. Clark (2011) analysed the development and evolution of a nighttime convective storm on 30 October 2008 over east Devon, United Kingdom, that caused flash flooding and unusually large accumulations of small hail $(10-20 \mathrm{~cm})$. Persistent strong low-level flow convergence, associated with a small surface mesolow, likely strongly increased the updraft speed of the storm, allowing high precipitation values in a relatively dry environment. For this hailstorm, orography also played a role, although secondary, with the local hills further mechanically enhancing ascent. An example of the importance of orography for supercells is given in Kunz et al. (2017), already mentioned in the Introduction, who studied the development, temporal evolution and impacts of an extreme supercell that occurred in southern Germany on 28 July 2013 and produced hail diameters up to $10 \mathrm{~cm}$. In this case study, ordinary cells developed first, with one transitioning to a damaging supercell through flow convergence at low-levels. This transition occurred in an area where wind shear and storm relative helicity were invigorated by the orography (Black Forest Mountains, up to $1500 \mathrm{~m}$ a.s.l. high).

\subsection{Implications for forecasting}

The four WRF simulations showed that thermo-topographic winds in the Alpine region, specifically Alpine pumping and mountain upslope winds, are represented in the model. Hail storms were generated in the Aare-Guerbe valleys in all four WRF simulations (Fig. 15), although the hail-producing storms differed in their exact location and longevity. This suggests that, while the exact location of hail occurrence may be difficult to simulate, the process of orographic forcing is well captured, and an ensemble of models may point to the region where severe convection will form, provided that orographic forcing is an important trigger for the region of the simulation. In all four WRF simulations, orography plays a role not only for the triggering of convective storms, but also for their propagation. Variability among the WRF simulations suggest, that the propagation and duration of the storms is sensitive to the time and location of the development of single 
storms and highly non-linear.

\section{Summary and conclusions}

In this study, we analysed a high-impact hail storm that formed in the complex topography of Switzerland on 6 June 2015. According to a 4-year convective storm statistic, storms with similar intensity occur about observational hail datasets we used to study the storm included crowd-sourced hail size reports, radarbased hail products, insurance loss data, and independent ground observations. The crowd-sourced data confirmed the presence of large hail at the ground indicated by radar and the ability of the MESHS product i) to identify areas with hail stones $\geq 2 \mathrm{~cm}$ and ii) to identify the areas with the largest diameters. of low-level moisture, atmospheric instability, and directional wind shear being present simultaneously over Switzerland. The instability was due to low- $\Theta_{e}$ air at mid-levels that was advected toward Switzerland around an anticyclone, and low-level moist air. Sources of this low-level moisture were the advection of air from the southwest ahead of an approaching cold front, and local moisture, which contributed to about a third of the total low-level moisture. The soil moisture had been supplied by abundant precipitation the day before in the area that the low-level air parcels crossed. The pre-convective environment on 6 June 2015 in northern Switzerland, was further characterised by a strong directional wind shear. This wind shear originated because of the contrast between mid-tropospheric flow from the south-southwest, which was driven by the synoptic weather systems, and flow at low-levels from the north-northeast, which was influenced by thermo-topographic processes (Alpine pumping).

To identify possible local-scale processes involved in the initiation and propagation of this severe hail storm, we used four WRF simulations. These simulations were run with ECMWF analysis data as initial and updated boundary conditions, and they were started several days ahead of the event. The WRF simulations produced hail storms comparable to the observed Thun storm, suggesting that the processes responsible for formation and development of the Thun storm were well-reproduced in the model. All four simulations produced a hail storm forming in the same region as observed in reality, pointing to predictive skill of the storm initiation. The initiation of storms in the northern Prealps in the simulations is associated with strong convergence at mountain tops, brought about by thermo-topographic winds. WRF simulations further suggested, that in the early phase of the storm's life cycle, its translation might have been driven by autopropagation via cold air outflow, that moved downslope to the valley bottom in the complex orography. The propagation of some of the simulated storms was connected to convergences at the valley bottoms, often but not exclusively caused by the outflow from storms on the mountain tops along the valleys. These convergences were highly sensitive to the timing of the storm outflows, the local topography, and the exact 
location where the cells formed. It is plausible that on 6 June 2015, together with the favourable directional wind shear, this mechanism influenced the longevity of the Thun storm.

In the future, a more quantitative analysis could be carried out to determine the importance of the local evapo-transpiration processes for convection in Switzerland. The simulation of further high-impact hail storms in the northern Prealps would allow a more comprehensive study of the involved processes, and a better understanding of the role of orography for hail storms in Switzerland.

The study was possible thanks to a unique combination of observational and model data over complex orography including dual-polarization radar measurements, model runs at $2 \mathrm{~km}$ resolution and a large number of crowd-sourced hail observations.

\section{Acknowledgements}

The authors thank Mobiliar Insurance Company for providing the hail claim data, MeteoSwiss and the ECMWF for granting access to ERA-Interim data, and the owners of the pictures for consenting to their publication. The authors further wish to thank Yannick Barton, Ulrich Hamann, Erica Madonna and Luca Nisi, who contributed to the early case study discussions and Paul Froidevaux for helping with the sounding data. This work was partly supported by the Swiss National Science Foundation (projects number 159905 and 156059). The presented research is an integral part of the first author's PhD thesis.

\section{References}

Adams-Selin, R. D., \& Ziegler, C. L. (2016). Forecasting hail using a one-dimensional hail growth model within WRF. Mon. Wea. Rev., 144, 4919-4939.

BAFU (2016). Umgang mit Naturgefahren in der Schweiz - Bericht des Bundesrats in Erfüllung des Postulats 12.4271 Darbellay vom 14.12.2012. Technical Report Bundesamt für Umwelt (BAFU), Bern, Switzerland.

Banacos, P., \& Ekster, M. L. (2010). The association of the elevated mixed layer with significant severe weather events in the Northeastern Unites States. Wea. Forecasting, 25, 1082-1102.

Banta, R. M. (1990). Atmospheric processes over complex terrain. Meteor. Monogr., 23, $183-203$.

Barthlott, C., Burton, R., Kirshbaum, D., Hanley, K., Richard, E., Chaboureau, J. P., Trentmann, J., Kern, B., Bauer, H. S., Schwitalla, T., Keil, C., Seity, Y., Gadian, A., Blyth, A., Mobbs, S., Flamant, C., \& Handwerker, J. (2011). Initiation of deep convection at marginal instability in an ensemble of mesoscale models: A case study from COPS. Quart. J. Roy. Meteor. Soc., 137, 118-136.

Besic, N., Figueras i Ventura, J., Grazioli, J., Gabella, M., Germann, U., \& Berne, A. (2016). Hydrometeor classification through statistical clustering of polarimetric radar measurements: A semi-supervised approach. Atmos. Meas. Tech., 9, 4425-4445.

Betschart, M., \& Hering, A. M. (2012). Automatic hail detection at MeteoSwiss. In Arbeitsberichte der MeteoSchweiz (p. 61). volume 238 .

Bider, M. (1954). Statistische Untersuchungen über Hagelhäufigkeit in der Schweiz und ihre Beziehung zur Grosswetterlage. Arch. Meteor. Geophys. Bioklimat., 6, 66-90. 
Bluestein, H. B. (1993). Synoptic-dynamic meteorology in Midlatitudes. Volume II: Observations and theory of weather systems. Oxford University Press.

Brimelow, J. C., Reuter, G. W., \& Poolman, E. R. (2002). Modeling maximum hail size in Alberta thunderstorms. Wea. Forecasting, 17, 1048-1062.

Brooks, H. E. (2009). Proximity soundings for severe convection for Europe and the United States from reanalysis data. Atmos. Res., 93, 546-553.

Capozzi, V., Piacciotti, E., Mazzarella, V., Marzano, F. S., \& Budillon, G. (2018). Fuzzy-logic detection and probability of hail exploiting short-range X-band weather radar. Atmos. Res., 201, 17-33.

Caracena, F., Maddox, R. A., Hoxit, L. R., \& Chappel, C. F. (1979). Mesoanalysis of the Big Thompson storm. Mon. Wea. Rev., 107, 1-17.

Chevuturi, A., Dimri, A. P., \& Gunturu, U. B. (2014). Numerical simulation of a rare winter hailstorm event over Delhi, India on 17 January 2013. Nat. Hazards Earth Syst. Sci., 14, 3331-3344.

Clark, M. R. (2011). An observational study of the exceptional Ottery St Mary thunderstorm of 30 October 2008. Meteorol. Appl., 18, 137-154.

Clough, S. A., Davitt, C. S. A., \& Thorpe, A. J. (1996). Attribution concepts applied to the omega equation. Quart. J. Roy. Meteor. Soc., 122, 1943-1962.

Craven, J. P., \& Brooks, H. E. (2004). Baseline climatology of sounding derived parameters associated with deep moist convection. Natl. Wea. Dig., 28, 13-24.

Davies, J. M., \& Johns, R. H. (1993). Some wind and instability parameters associated with strong and violent tornadoes. Part I: Wind shear and helicity. In The Tornado: Its Structure, Dynamics, Prediction, and Hazards, Geophys. Monogr. (pp. 573-582).

Dee, D. P., Uppala, S. M., Simmons, A. J., Berrisford, P., Poli, P., Kobayashi, S., Andrae, U., Balmaseda, M. A., Balsamo, G., Bauer, P., Bechtold, P., Beljaars, A. C. M., van de Berg, L., Bidlot, J., Bormann, N., Delsol, C., Dragani, R., Fuentes, M., Geer, A. J., Haimberger, L., Healy, S. B., Hersbach, H., Hólm, E. V., Isaksen, L., Kållberg, P., Köhler, M., Matricardi, M., McNally, A. P., Monge-Sanz, B. M., Morcrette, J. J., Park, B. K., Peubey, C., de Rosnay, P., Tavolato, C., Thépaut, J. N., \& Vitart, F. (2011). The ERA-Interim reanalysis: Configuration and performance of the data assimilation system. Quart. J. Roy. Meteor. Soc., 137, 553-597.

Doswell III, C. A. (1987). The distinction between large-scale and mesoscale contribution to severe convection: A case study example. Wea. Forecasting, 2, 3-16.

Doswell III, C. A., \& Evans, J. S. (2003). Proximity sounding analysis for derechos and supercells: An assessment of similarities and differences. Atmos. Res., 67-8, 117-133.

Dotzek, N., Groenemeijer, P., Feuerstein, B., \& Holzer, A. M. (2009). Overview of ESSLs severe convective storms research using the European Severe Weather Database ESWD. Atmos. Res., 93, 575-586.

Ek, M. B., \& Holtslag, A. A. M. (2004). Influence of soil moisture on boundary layer cloud development. J. Hydrometeorol., $5,86-99$.

Elmore, K. L., Flamig, Z. L., Lakshmanan, V., Kaney, B. T., Farmer, V., Reeves, H. D., \& Rothfusz, L. P. (2014). MPING: Crowd-sourcing weather reports for research. Bull. Amer. Meteor. Soc., 95, 1335-1342.

Eltahir, E. A. B., \& Bras, R. L. (1996). Precipitation recycling. Rev. Geophys., 34, 367-378.

Federer, B., Waldvogel, A., Schmid, W., Hampel, F., Rosini, E., Vento, D., Admirat, P., \& Mezeix, J. F. (1978). Plan for the Swiss randomized hail suppression experiment - Design of Grossversuch IV. Pure and Applied Geophysics, 117, 548-571.

Findell, K. L., \& Eltahir, E. A. B. (1997). An analysis of the soil moisture-rainfall feedback, based on direct observations from Illinois. Water Resour. Res., 33, 725-735.

Foote, G. A., Krauss, T. W., \& Makitov, V. (2005). Hail metrics using convectional Radar. In Proceedings of the $16^{\text {th }}$ 
Conference on Planned and Inadvertent Weather Modification, San Diego, CA, USA.

Froidevaux, P., Schlemmer, L., Schmidli, J., Langhans, W., \& Schär, C. (2014). Influence of the background wind on the local soil moisture-precipitation feedback. J. Atmos. Sci., 71, 782-799.

García-Ortega, E., Fita, L., Romero, R., López, L., Ramis, C., \& Sánchez, J. L. (2007). Numerical simulation and sensitivity study of a severe hailstorm in northeast Spain. Atmos. Res., 83, 225-241.

García-Ortega, E., Hemida, L., Hierro, R., Merino, A., Gascón, E., Fernández-Gonzáles, S., Sánchez, J. L., \& López, L. (2014). Anomalies, trends and variability in atmospheric fields related to hailstorms in north-eastern Spain. Int. J. Climatol., 34 , 3251-3263.

Gascón, E., Lavoia, S., Merino, A., \& Miglietta, M. M. (2016). Analysis of a localized flash-flood event over the central Mediterranean. Atmos. Res., 182, 256-268.

Gascón, E., Merino, A., Sánchez, J. L., Fernández-Gonzáles, S., García-Ortega, E., López, L., \& Hemida, L. (2015). Spatial distribution of thermodynamic conditions of severe storms in southwestern Europe. Atmos. Res., 164-165, $194-209$.

Germann, U., Boscacci, M., Gabella, M., \& Sartori, M. (2015). Radar design for prediction in the Swiss Alps. Meteorol. Techn. Int., 4, 42-45.

Germann, U., Figueras i Ventura, J., Gabella, M., Hering, A., Sideris, I., \& Calpini, B. (2016). Triggering innovation The latest MeteoSwiss Alpine weather radar network. Meteorol. Techn. Int., 4, 62-65.

Giaiotti, D., Nordio, S., \& Stel, F. (2003). The climatology of hail in the plain of Friuli Venezia Giulia. Atmos. Res., 67-8, $247-259$.

Groenemeijer, P. H., \& van Delden, A. (2007). Sounding-derived parameters associated with large hail and tornadoes in the Netherlands. Atmos. Res., 83, 473-487.

Groenemeijer, P. H., Pik, T., Holzer, A. M., Antonescu, B., Riemann-Campe, K., Schultz, D. M., Khne, T., Feuerstein, B., Brooks, H. E., Doswell III, C. A., Koppert, H. J., \& Sausen, R. (2017). Severe convective storms in Europe: Ten years of research at the European Severe Storms Laboratory. Bull. Amer. Meteor. Soc., Early Online Release, .

Guillod, B. P., Orlowsky, B., Miralles, D. G., Teuling, A. J., \& Seneviratne, S. I. (2015). Reconciling spatial and temporal soil moisture effects on afternoon rainfall. Nat. Commun., 6, 1-6.

Hafner, T. A., Reinhard, M. E., Weisel, E. L., \& Fimpel, H. P. (1987). Boundary layer aspects an elevated heat source effects of the Alps. Meteorol. Atmos. Phys., 36, 61-73.

Hagen, M., van Baelen, J., \& Richard, E. (2011). Influence of the wind profile on the initiation of convection in mountainous terrain. Quart. J. Roy. Meteor. Soc., 137, 224-235.

Hering, A. M., Germann, U., Boscacci, M., \& Sénési, S. (2008). Operational nowcasting of thunderstorms in the Alps during MAP D-PHASE. In Proceedings of $5^{\text {th }}$ European Conference on Radar in Meteorology and Hydrology, Göttingen, Germany.

Hering, A. M., Morel, C., Galli, G., Sénési, S., Ambrosetti, P., \& Boscacci, M. (2004). Nowcasting thunderstorms in the Alpine region using a radar based adaptive thresholding scheme. In Proceedings of the $3^{\text {rd }}$ European Conference Radar in Meteorology and Hydrology, Visby, Sweden.

Hoskins, B. J., Draghici, I., \& Davies, H. C. (1978). A new look at the w-equation. Quart. J. Roy. Meteor. Soc., 104, 31-38. Houze, R. A. (2012). Orographic effects on precipitation and clouds. Rev. Geophys., 50, RG1001.

Houze, R. A., Schmid, W., Fovell, R. G., \& Schiesser, H. H. (1993). Hailstorms in Switzerland: Left movers, right movers and false hooks. Mon. Wea. Rev., 121, 3345-3370.

Joe, P., Burgess, D., Potts, R., Keenan, T., Stumpf, G., \& Treloar, A. B. A. (2004). The S2K severe weather detection algorithms and their performance. Wea. Forecasting, 19, 43-63.

Johns, R. H., \& Doswell III, C. A. (1992). Severe local storms forecasting. Wea. Forecasting, 7, 588-612.

Kaltenböck, R. (2004). The outbreak of severe storms along convergence lines northeast of the Alps. Case study of the 3 August 2001 mesoscale convective system with a pronounced bow echo. Atmos. Res., 70, 55-75. 
Kaltenböck, R., Diendorfer, G., \& Dotzek, N. (2009). Evaluation of thunderstorm indices from ECMWF analyses, lightning data and severe storm reports. Atmos. Res., 93, 381-396.

Kottmeier, C., Kalthoff, N., Barthlott, C., Corsmeier, U., van Baelen, J., Behrendt, R., Blyth, A., Coulter, R., Crewell, S., Di Girolamo, P., Dorninger, M., Flamant, C., Foken, T., Hagen, M., Hauck, C., Hller, H., Konow, H., Kunz, M., Mahlke, H., Mobbs, S., Richard, E., Steinacker, R., Weckwerth, T., Wieser, A., \& Wulfmeyer, V. (2008). Mechanisms initiating deep convection over complex terrain during COPS. Meteor. Z., 17, 931-948.

Kunz, M., Blahak, U., Handwerker, J., Schmidberger, M., Punge, H. J., Mohr, S., Fluck, E., \& Bedka, K. M. (2017). The severe hailstorm in southwest Germany on 28 July 2013: Characteristics, impacts and meteorological conditions. Q.J.R. Meteorol. Soc., . In press.

Kunz, M., \& Puskeiler, M. (2010). High-resolution assessment of the hail hazard over complex terrain from Radar and insurance data. Meteor. Z., 19, 427-439.

Leslie, L. M., Leplastrier, M., \& Buckley, B. W. (2008). Estimating future trends in severe hailstorms over the Sydney Basin: A climate modelling study. Atmos. Res., 87, 37-51.

Leuenberger, D. (2005). High-resolution radar rainfall assimilation: Exploratory studies with latent heat nudging. Ph.D. thesis ETH Zurich, Switzerland.

Mahoney, K., Alexander, M. A., Thompson, G., Barsugli, J. J., \& Scott, J. D. (2012). Changes in hail and flood risk in high-resolution simulations over Colorado's mountains. Nat. Clim. Change, 2, 125-131.

Markowski, P., \& Richardson, Y. (2010). Mesoscale meteorology in midlatitudes. Wiley-Blackwell, Chirchester, UK.

Martius, O., Sodemann, H., Joos, H., Pfahl, S., Winschall, A., Croci-Maspoli, M., Graf, M., Madonna, E., Mueller, B., Schemm, S., Sedlacek, J., Sprenger, M., \& Wernli, H. (2013). The role of upper-level dynamics and surface processes for the Pakistan flood of July 2010. Quart. J. Roy. Meteor. Soc., 139, 1780-1797.

Morel, S. (2014). Verification of radar-based hail detection algorithms with insurance loss data in Switzerland. Master's thesis University of Bern, Switzerland.

Morrison, H., Thompson, G., \& Tatarskii, V. (2009). Impact of cloud microphysics on the development of trailing stratiform precipitation in a simulated squall line: Comparison of one- and two-moment schemes. Mon. Wea. Rev., 137, 991-1007.

Nisi, L., Hering, A., Germann, U., \& Martius, O. (2018). A 15-year hail streak climatology for the alpine region. Quart. J. Roy. Meteor. Soc., in press.

Nisi, L., Martius, O., Hering, A., Kunz, M., \& Germann, U. (2016). Spatial and temporal distribution of hailstorms in the Alpine region: A long-term, high resolution, radar-based analysis. Quart. J. Roy. Meteor. Soc., 142, 1590-1604.

Noppel, H., Blahak, U., Seifert, A., \& Beheng, K. D. (2010). Simulations of a hailstorm and the impact of CCN using and advanced two-moment cloud microphysical scheme. Atmos. Res., 96, 286-301.

Pedgley, D. E. (2003). The Bracknell hailstorm of 7 May 2000. Weather, 58, 171-182.

Peyraud, L. (2013). Analysis of the 18 July 2005 tornadic supercell over the Lake Geneva Region. Wea. Forecasting, 28, $1524-1551$.

Pućik, T., Groenemeijer, P., Ryva, D., \& Kolar, M. (2015). Proximity soundings of severe and nonsevere thunderstorms in Central Europe. Mon. Wea. Rev., 143, 4805-4821.

Rotach, M. W., Ambrosetti, P., Ament, F., Appenzeller, C., Arpagaus, M., Bauer, H. S., Behrendt, A., Bouttier, F., Buzzi, A., Corazza, M., Davolio, S., Denhard, M., Dorninger, M., Fontannaz, L., Frick, J., Fundel, F., Germann, U., Gorgas, T., Hegg, C., Hering, A., Keil, C., Liniger, M. A., Marsigli, C., McTaggart-Cowan, R., Montaini, A., Mylne, K. R. R., Richard, E., Rossa, A., Santos-Munoz, D., Schaer, C., Seity, Y., Staudinger, M., Stoll, M., Volkert, H., Walser, A., Wang, Y., Werhahn, J., Wulfmeier, W., \& Zappa, M. (2009). MAP D-PHASE: Real-time demonstration of weather forecast quality in the Alpine region. Bull. Am. Meteorol. Soc., 90, 1321-1336.

Rotunno, R., \& Ferretti, R. (2001). Mechanisms of intense Alpine rainfall. J. Atmos. Sci., 58, 1732-1749. 
Rotunno, R., \& Houze, R. A. (2007). Lessons on orographic precipitation from the Mesoscale Alpine Programme. Quart. J. Roy. Meteor. Soc., 133, 811-830.

Rotunno, R., Klemp, J. B., \& Weisman, M. L. (1988). A theory for strong, long-lived squall lines. J. Atmos. Sci., 45, 463-485.

Rudari, R., Entekhabi, D., \& Roth, G. (2004). Terrain and multiple-scale interactions as factors in generating extreme precipitation events. J. Hydrometeorol., 5, 390-404.

Schättler, U., Doms, G., \& Schraff, C. (2008). A description of the non-hydrostatic regional COSMO-model, Part VII: User's guide. Technical Report. Available at www.cosmo-model.org.

Schemm, S., Nisi, L., Martinov, A., Leuenberger, D., \& Martius, O. (2016). On the link between cold fronts and hail in Switzerland. Atmos. Sci. Lett., 17, 315-325.

Schlemmer, L., \& Hohenegger, C. (2014). The formation of wider and deeper clouds as a result of cold-pool dynamics. J. Atmos. Sci., 71, 2842-2858.

Schmid, W., Schiesser, H. H., \& Bauer-Messmer, B. (1997). Supercell storms in Switzerland: Case studies and implications for nowcasting severe winds with Doppler radar. Meteor. Appl., 4, 49-67.

Schmid, W., Schiesser, H. H., Furger, M., \& Jenni, M. (2000). The origin of severe winds in a tornadic bow-echo storm over northern Switzerland. Mon. Wea. Rev., 128, 192-207.

Seimon, A., Allen, J. T., Seimon, T., Talbot, S., Hoadley, D., \& Edwards, E. (2016). Crowd-sourcing the El Reno 31st May 2013 Tornado: Making Storm Chaser Visual Observations Scientific. Bull. Amer. Meteor. Soc., 97, $2069-2084$.

Smith, P. L., \& Waldvogel, A. (1989). On determinations of maximum hailstone sizes from hailpad observations. Journal of Applied Meteorology, 28, 71-76.

Sprenger, M., \& Wernli, H. (2015). The LAGRANTO Lagrangian analysis tool - version 2.0. Geosci. Model Dev., 8, 2569-2586.

Stephan, K., Klink, S., \& Schraff, C. (2008). Assimilation of radar-derived rain rates into the convective-scale model COSMODE at DWD. Quart. J. Roy. Meteor. Soc., 134, 1315-1326.

Stone, H. L. (1968). Iterative solution of implicit approximations of multidimensional partial differential equations. SIAM $J$. Num. Anal., 5, 530-558.

Taszarek, M., Brooks, H. E., \& Czernecki, B. (2017). Sounding-derived parameters associated with convective hazards in Europe. Mon. Wea. Rev., 145, 1511-1528.

Thompson, G., Field, P. R., Rasmussen, R. M., \& Hall, W. D. (2008). Explicit forecasts of winter precipitation using an improved bulk microphysics scheme. Part II: Implementation of a new snow parameterization. Mon. Wea. Rev., 136, $5095-5115$.

Trefalt, S. (2017). Hail and severe wind gusts in the convective season in Switzerland. Ph.D. thesis University of Bern, Switzerland.

Treloar, A. B. A. (1998). Vertically integrated radar reflectivity as an indicator of hail size in the greater Sydney region of Australia. In Proceedings of the 19th Conference on Severe Local Storms, Minneapolis, MN, USA (pp. 48-51).

VKF (2007). Wegleitung Objektschutz gegen meteorologische Naturgefahren - Hagel. Technical Report Vereinigung Kantonaler Feuerversicherungen (VKF).

VKF (2013). Naturgefahren und Prävention innerhalb der VKF. Technical Report Vereinigung Kantonaler Feuerversicherungen $(\mathrm{VKF})$.

Waldvogel, A., Federer, B., \& Grimm, P. (1979). Criteria for the detection of hail cells. J. Appl. Meteor., 18, $1521-1525$.

Webb, R. M., Treloar, A. B. A., Colquhoun, J. R., Potts, R. J., Bally, J., Keenan, T. D., \& May, P. T. (2001). Overview of Sydney weather during the Forecast Demonstration Project. In Preprints of $30^{\text {th }}$ International Conference on Radar Meteorology, Munich, Germany (pp. 477-479).

Willemse, S. (1995). A statistical analysis and climatological interpretation of hailstorms in Switzerland. Ph.D. thesis ETH 
Willemse, S., \& Furger, M. (Eds.) (2016). From weather observations to atmospheric and climate sciences in Switzerland Celebrating 100 years of the Swiss Society for Meteorology. vdf Hochschulverlag AG.

Wu, X., \& Li, X. (2008). A review of cloud-resolving model studies of convective processes. Adv. Atmos. Sci., 25, 202-212. 


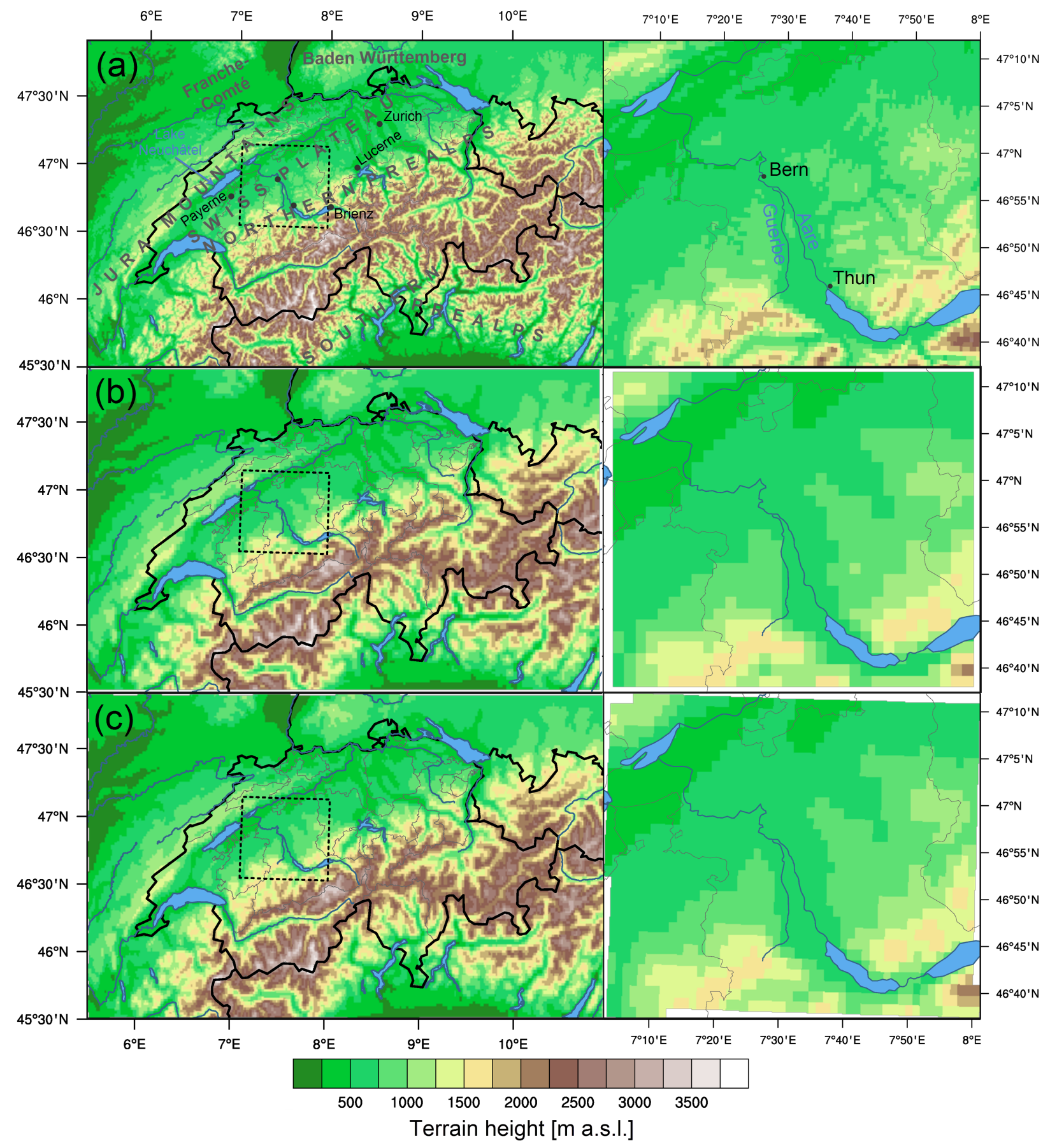

Figure 1: Terrain [m a.s.l.] of (a) a digital elevation model with 30 arc-minute resolution, (b) COSMO-2 model (2.2 km resolution) and (c) WRF model (2.14 km by $1.35 \mathrm{~km}$ resolution) showing Switzerland (left panels) and the Thun-Bern region (see box in Fig. 1 , right panels). In (a) are indicated the topographic regions (capitalised), major cities (black), lakes and rivers mentioned in the text. 


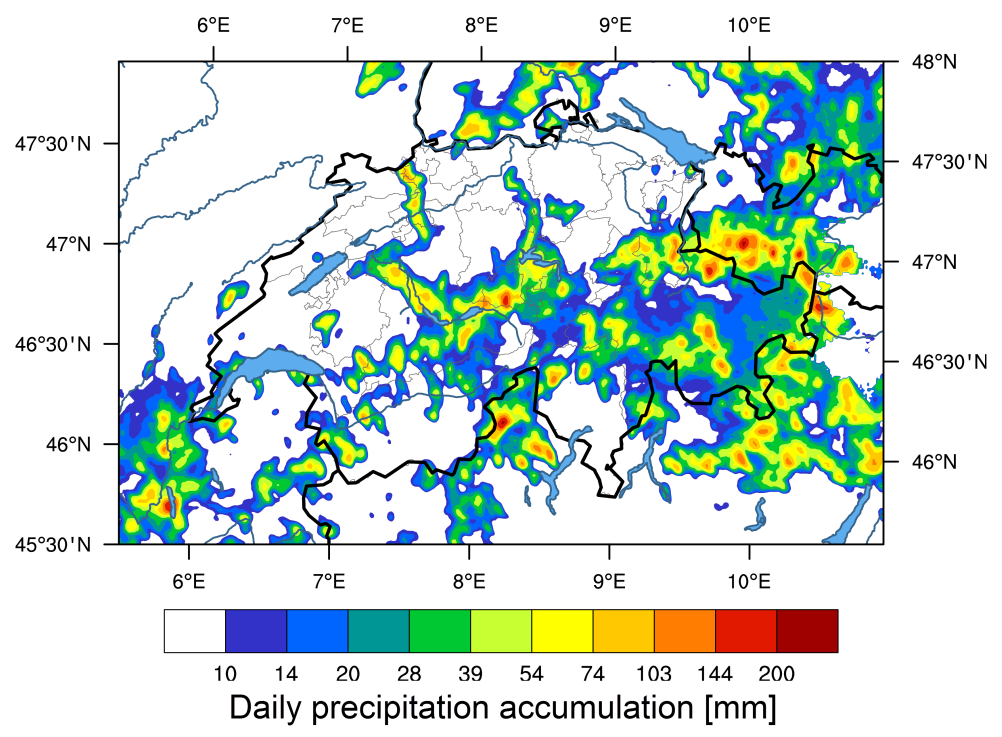

Figure 2: Radar-derived daily precipitation accumulation $[\mathrm{mm}]$ in Switzerland and neighbouring regions from 0000 UTC to 2355 UTC 6 June 2015. 


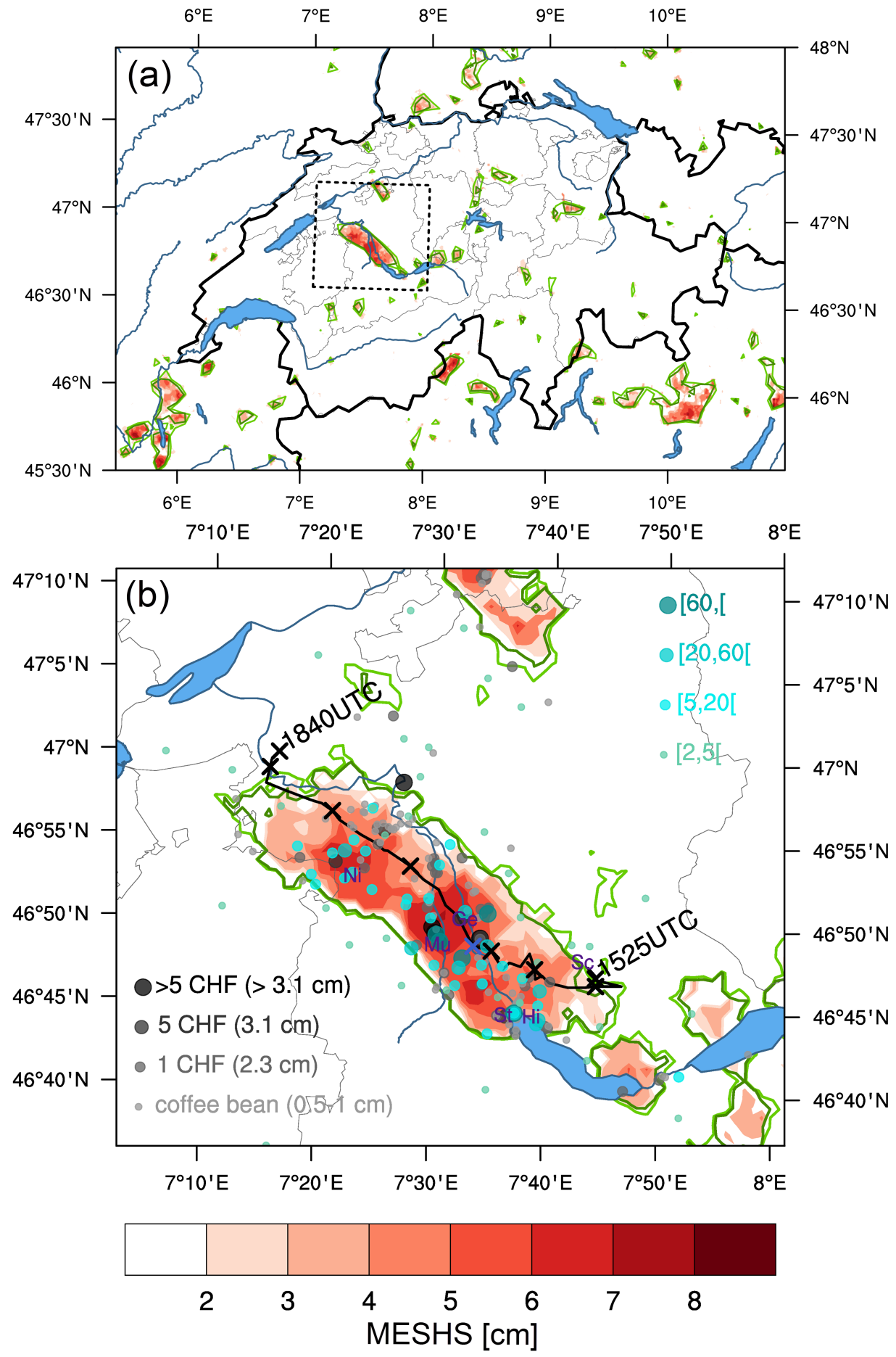

Figure 3: (a) Daily maximum MESHS [cm] (colour) and smoothed POH [\%] (contours; light green $=80 \%$, dark green $=90$ \%) for Switzerland, and (b) zoom to the Thun-Bern region (cf., box in Fig. 3a) with MESHS [cm], POH [\%] (as Fig. 33), Thun storm track (black line; start, end, and location every 30 min as black x, and 1700 UTC as blue x), MeteoSwiss App hail reports (gray points; size/shade shows hail size: 'Coffee bean' $=0.5-0.8 \mathrm{~cm}$, ' $1 \mathrm{CHF}$ coin' $=2.3 \mathrm{~cm},{ }^{5} 5 \mathrm{CHF}$ coin' $=3.1$ cm, and ' $>5$ CHF coin'), insurance damage reports (blue points; size/shade shows claims per postcode: 2-4, 5-19, 20-59, and $>60$ claims), and location of ESWD reports and photographic verification material (purple; Ge=Gerzensee, Hi=Hilterfingen, $\mathrm{Mu}=$ Muelethurnen, $\mathrm{Ni}=$ Niederscherli, $\mathrm{Sc}=$ Schwarzenegg and $\mathrm{St}=$ Stockhorn). 


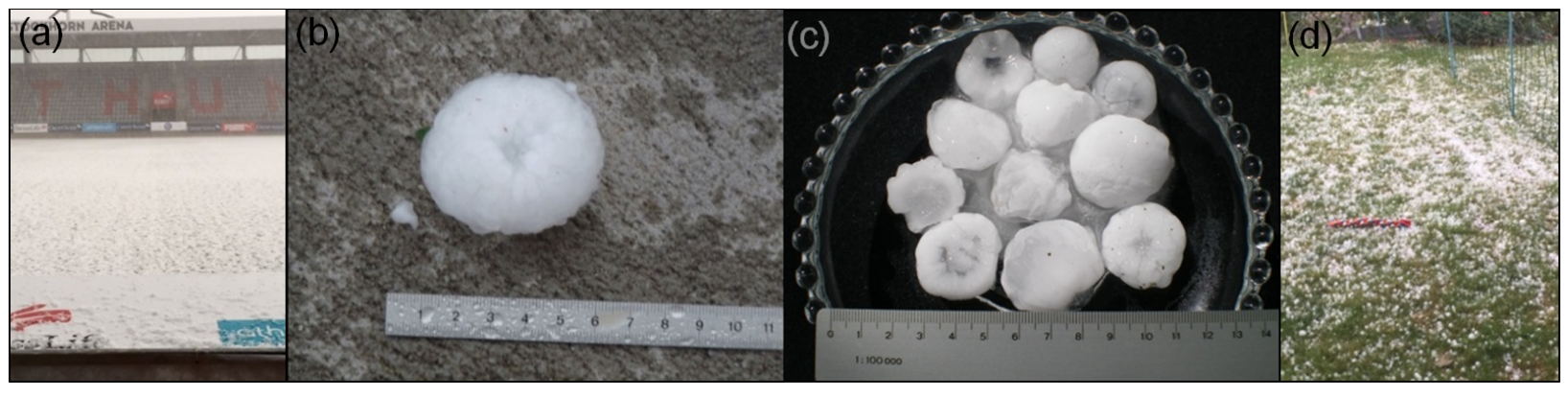

Figure 4: Photos of hail along the Thun storm track. Images (a)-(d) taken in the Stockhorn stadium in Thun, Muelethurnen, Gerzensee and Hilterfingen (see Fig. 3p for locations). Photos (a) and (d) show a large amount of hail, while photo (b) and (c) show hail stones with diameters of $6 \mathrm{~cm}$ and $4 \mathrm{~cm}$. Sources: E. A. Schenk, M. Imhof, K. C. Ewald, S. Hamstra. 

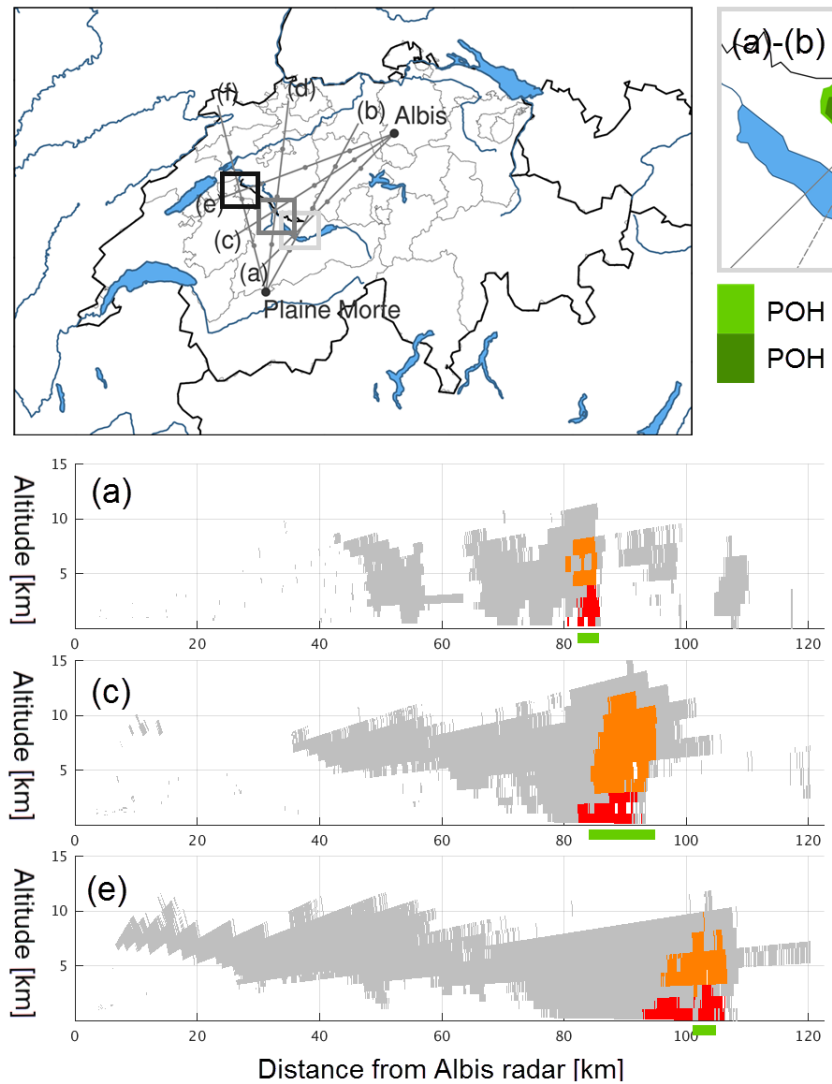

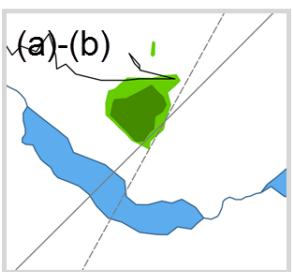

$\mathrm{POH} 80-90 \%$

$\mathrm{POH}>90 \%$
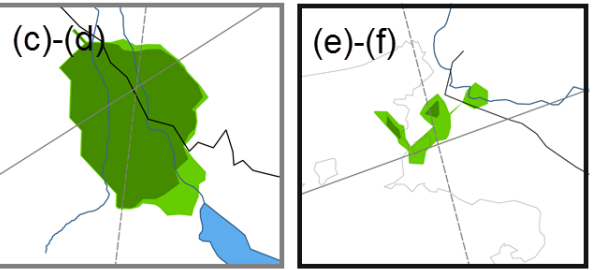

melting hail

ice hail and high density graupel

other hydrometeor classes
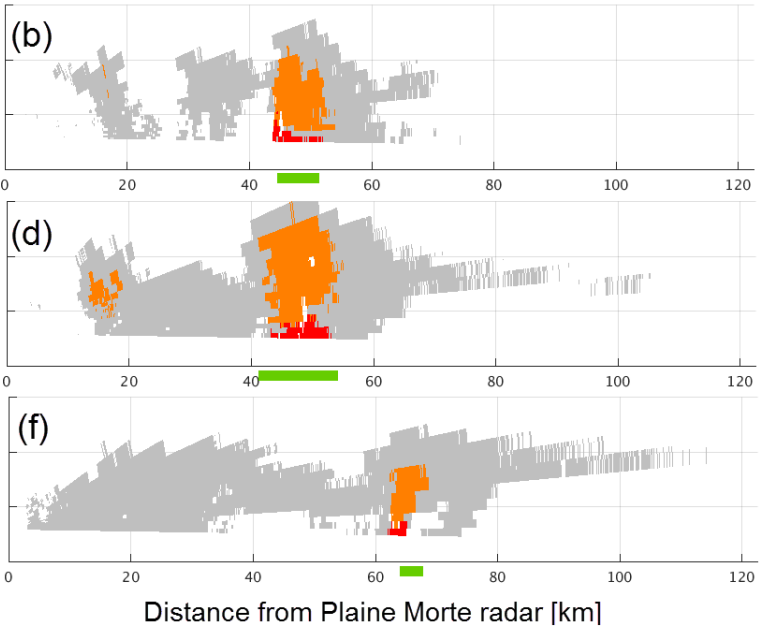

Figure 5: Radar RHIs showing the hydrometeor classification for (a)-(b) 1550 UTC, (c)-(d) 1700 UTC, and (e)-(f) 1805 UTC 6 June 2015. (a), (c), and (e) are RHIs from Albis radar, while (b), (d), and (f) are from Plaine Morte radar. The RHIs show the 'melting hail' and 'ice hail and high density graupel' classes in colour, and all other classes in gray. The surface section with $\mathrm{POH} \geq 80 \%$ is indicated as light green line on the RHI x-axis. On the top left are the location of the RHIs for each time, and on the top right are planar views showing the areas with $\mathrm{POH} \geq 80 \%$ (light green) and $\geq 90 \%$ (dark green). 

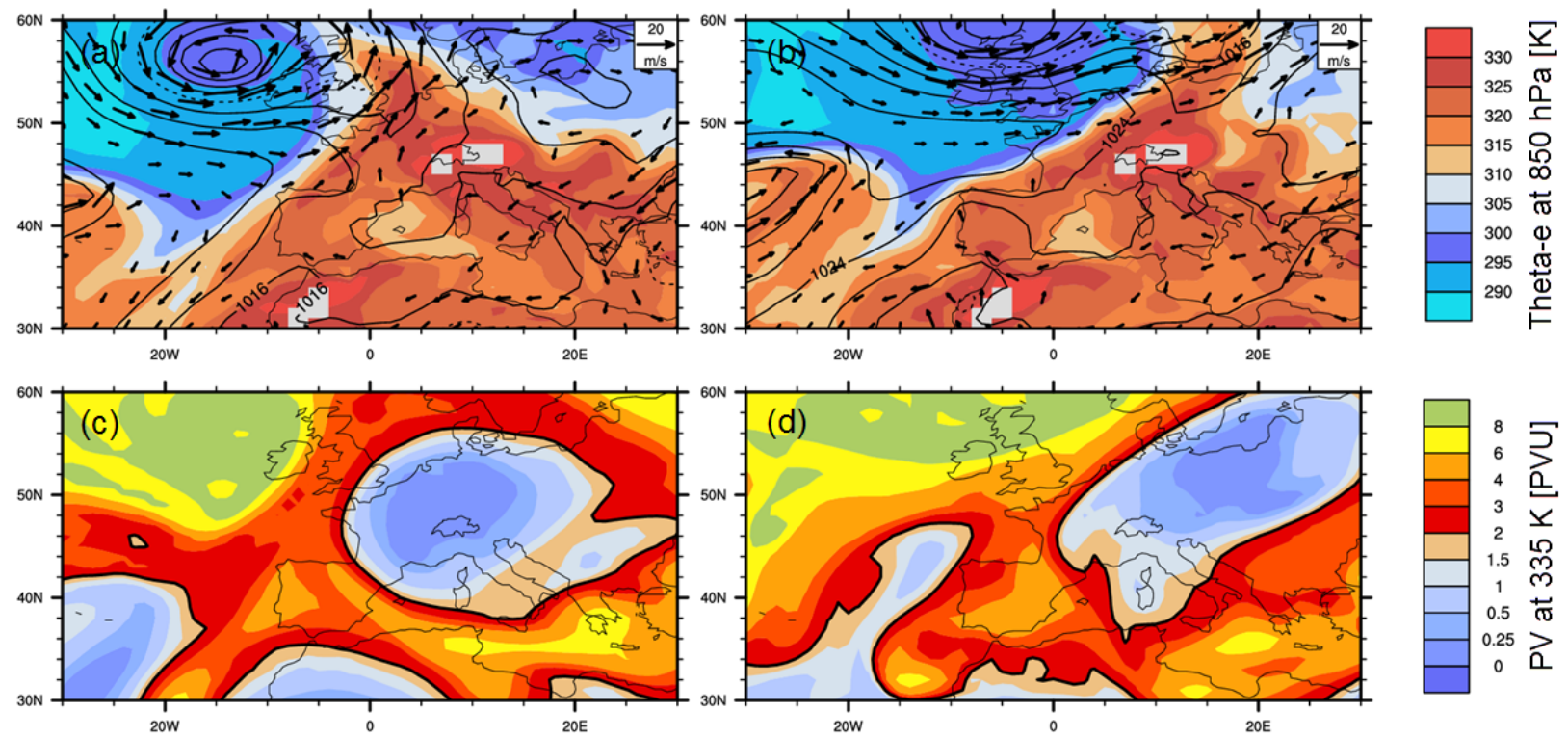

Figure 6: $\Theta_{e}$ at $850 \mathrm{hPa}[\mathrm{K}]$ (colour), wind at $850 \mathrm{hPa}\left[\mathrm{m} \mathrm{s}^{-1}\right]$ (arrows), and sea level pressure [hPa] (contours) for (a) 1200 UTC 5 June 2015 and (b) 1200 UTC 6 June 2015. PV at 335 K [PVU] (colour) with black line the 2 PVU-isoline for (c) 1200 UTC 5 June 2015 and (d) 1200 UTC 6 June 2015. 


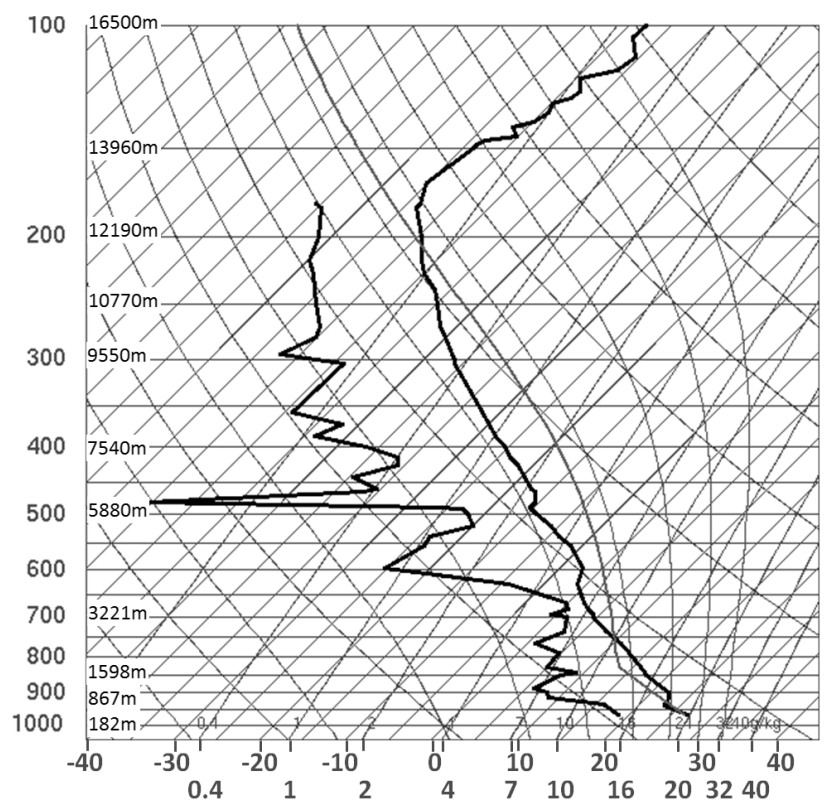

Figure 7: Skew-T log-P diagram of atmospheric radio-sounding at Payerne, Switzerland launched at 1200 UTC 6 June 2015. The left curve is the dewpoint and the right curve is the temperature. Adapted from: University of Wyoming, http://weather. uwyo.edu/upperair/sounding.html 

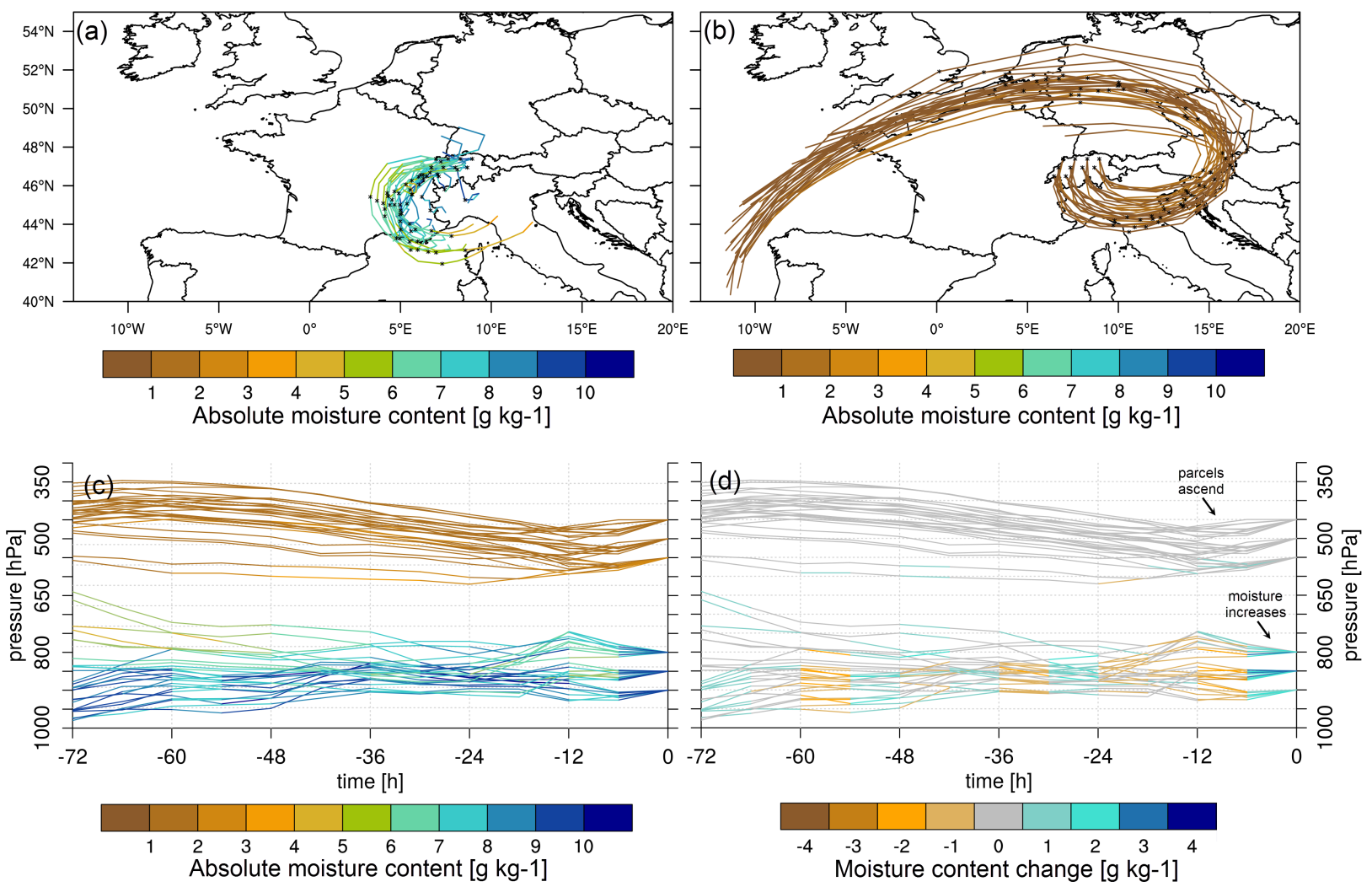

Figure 8: Three-day-backwards-trajectories started from northern Switzerland at 1200 UTC 6 June 2015 at (a) low- and (b) mid-levels. Shown are the absolute moisture $\left[\mathrm{g} \mathrm{kg}^{-1}\right]$ every $6 \mathrm{~h}$ (colour), and the starting points of the trajectories and their position one and two days prior (black asterisks). Also shown are 6-hourly (c) absolute moisture $\left[\mathrm{g} \mathrm{kg}^{-1}\right]$ (colour) and (d) moisture change $\left[\mathrm{g} \mathrm{kg}^{-1}\right.$ ] (colour) of the trajectories started at low- and mid-levels. The ten starting coordinates are $46^{\circ} 29^{\prime} \mathrm{N}$ $6^{\circ} 27^{\prime} \mathrm{E}, 46^{\circ} 29^{\prime} \mathrm{N} 7^{\circ} 60^{\prime} \mathrm{E}, 46^{\circ} 56^{\prime} \mathrm{N} 6^{\circ} 41^{\prime} \mathrm{E}, 46^{\circ} 56^{\prime} \mathrm{N} 7^{\circ} 21^{\prime} \mathrm{E}, 46^{\circ} 56^{\prime} \mathrm{N} 8^{\circ} 10^{\prime} \mathrm{E}, 46^{\circ} 56^{\prime} \mathrm{N} 8^{\circ} 40^{\prime} \mathrm{E}, 47^{\circ} 23^{\prime} \mathrm{N} 6^{\circ} 57^{\prime} \mathrm{E}, 47^{\circ} 23^{\prime}$ $\mathrm{N} 7^{\circ} 37^{\prime} \mathrm{E}, 47^{\circ} 23^{\prime} \mathrm{N} 8^{\circ} 17^{\prime} \mathrm{E}$, and $47^{\circ} 23^{\prime} \mathrm{N} 8^{\circ} 57^{\prime} \mathrm{E}$ 


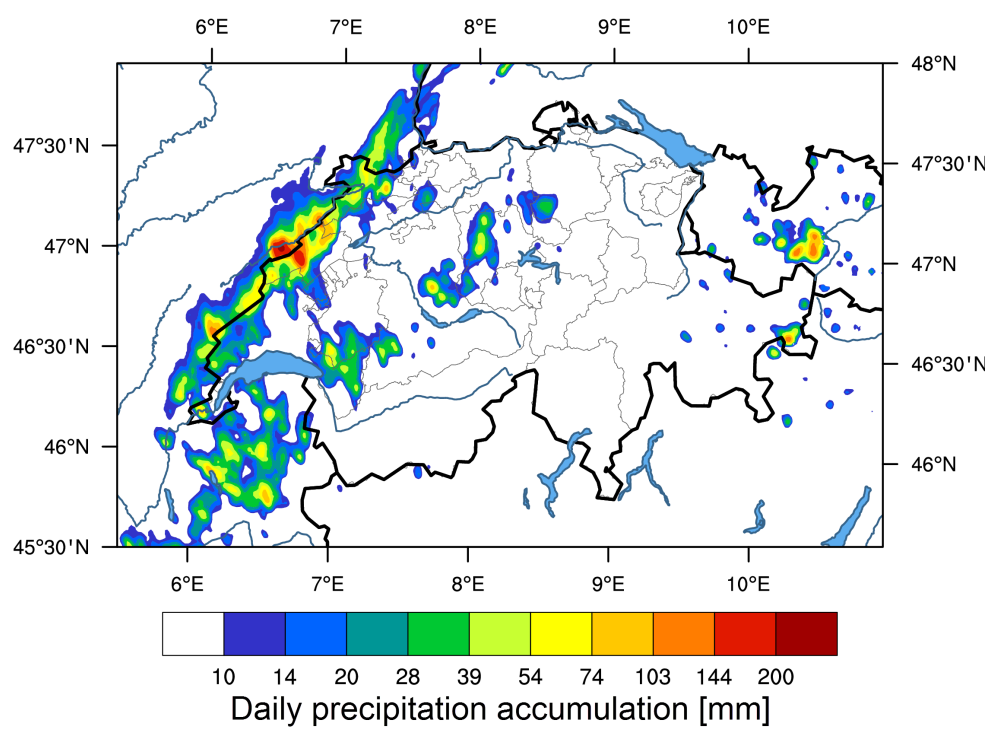

Figure 9: Radar-derived daily precipitation accumulation $[\mathrm{mm}]$ in Switzerland and neighbouring regions from 0000 UTC to 2355 UTC 5 June 2015. 


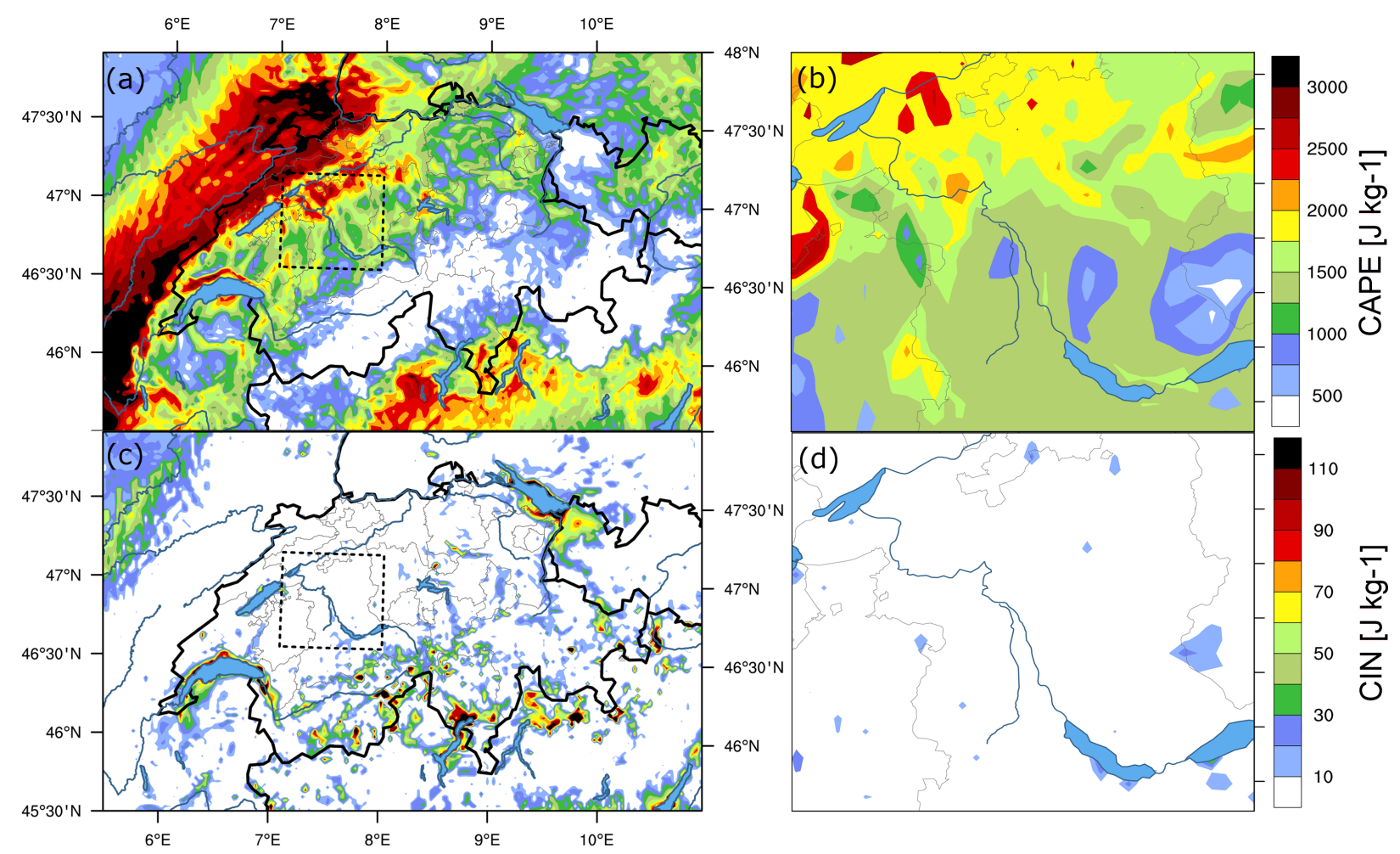

Figure 10: (a)-(b) COSMO-2 CAPE of the most unstable layer [ $\left.\mathrm{J} \mathrm{kg}^{-1}\right]$ and (c)-(d) CIN of the most unstable layer [ $\left.\mathrm{J} \mathrm{kg}^{-1}\right]$. The left figures show Switzerland at 1300 UTC 6 June 2015 and the right figures show the Thun-Bern region (see box in (a) and (c)) at 1500 UTC 6 June 2015. 


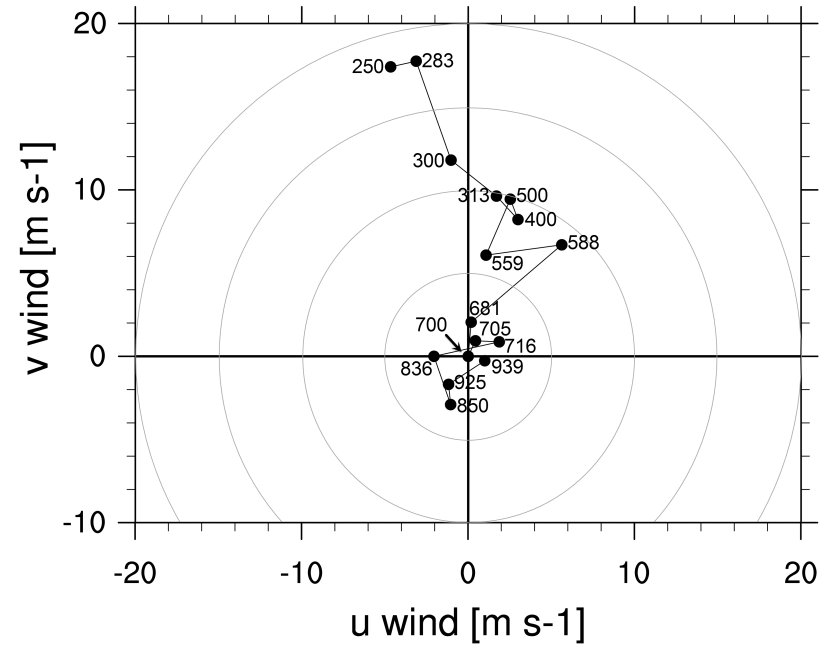

Figure 11: Hodograph derived from Payerne sounding of 1200 UTC 6 June 2015 with indication of pressure levels [hPa]. Adapted from: University of Wyoming, http://weather.uwyo.edu/upperair/sounding.html 

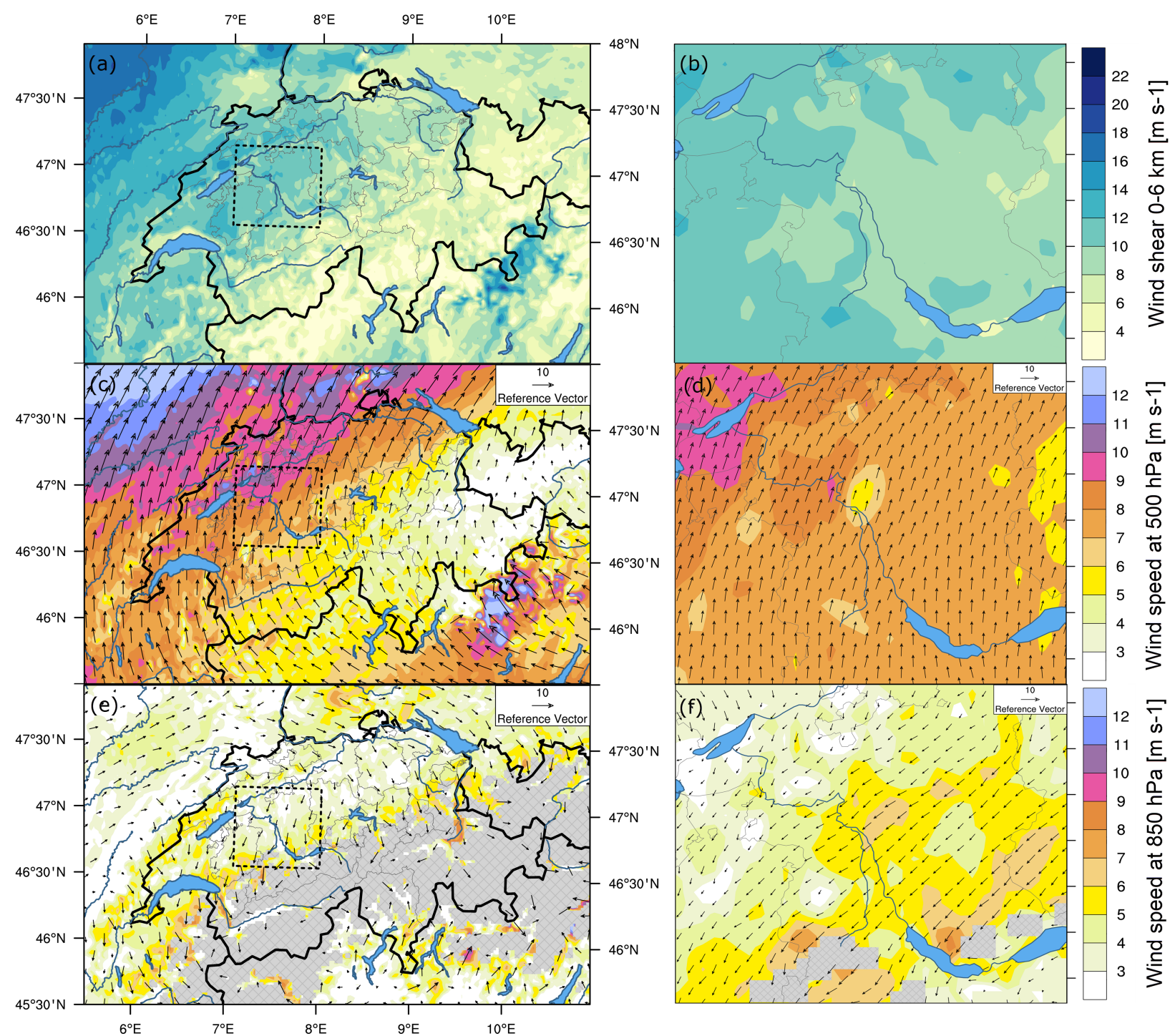

Figure 12: (a)-(b) COSMO-2 bulk wind shear 0-6 km $\left[\mathrm{m} \mathrm{s}^{-1}\right]$, (c)-(d) wind speed $\left[\mathrm{m} \mathrm{s}^{-1}\right]$ and direction at $500 \mathrm{hPa}$ and (e)-(f) $850 \mathrm{hPa}$. The left panels show Switzerland at 1300 UTC 6 June 2015 and the right figures show the Thun-Bern region (see box in (a), (c) and (e)) at 1500 UTC 6 June 2015. 

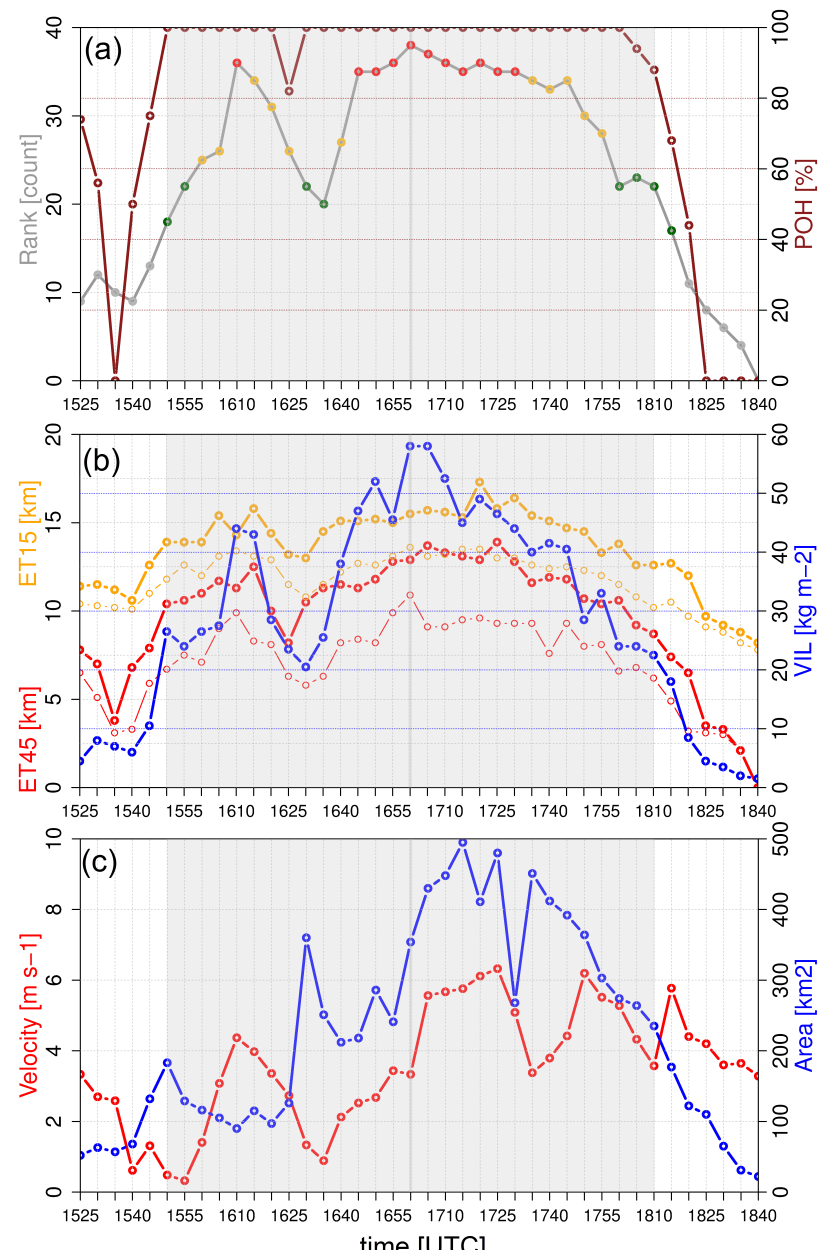

Figure 13: Radar-derived properties of the Thun storm in 5 min intervals from 1525 to 1840 UTC 6 June 2015. (a) TRT severity ranking (possible values: 0-40; gray line; coloured circles indicate severity class: gray $=$ no classification or 'weak', green $=$ 'moderate', yellow = 'severe', red = 'very severe'), and POH [\%] (maroon). (b) Storm-area median/maximum ET15 [km] (thin/thick yellow), storm-area median/maximum ET45 [km] (thin/thick red) and VIL [kg m$\left.{ }^{-2}\right]$ (blue). (c) Storm velocity [m $\left.\mathrm{s}^{-1}\right]$ (red) and storm area $\left[\mathrm{km}^{2}\right]$ (blue). The gray box indicates the time of probable hail at the ground (POH $\left.\geq 80 \%\right)$ and the dark gray line indicates the most severe stage. 


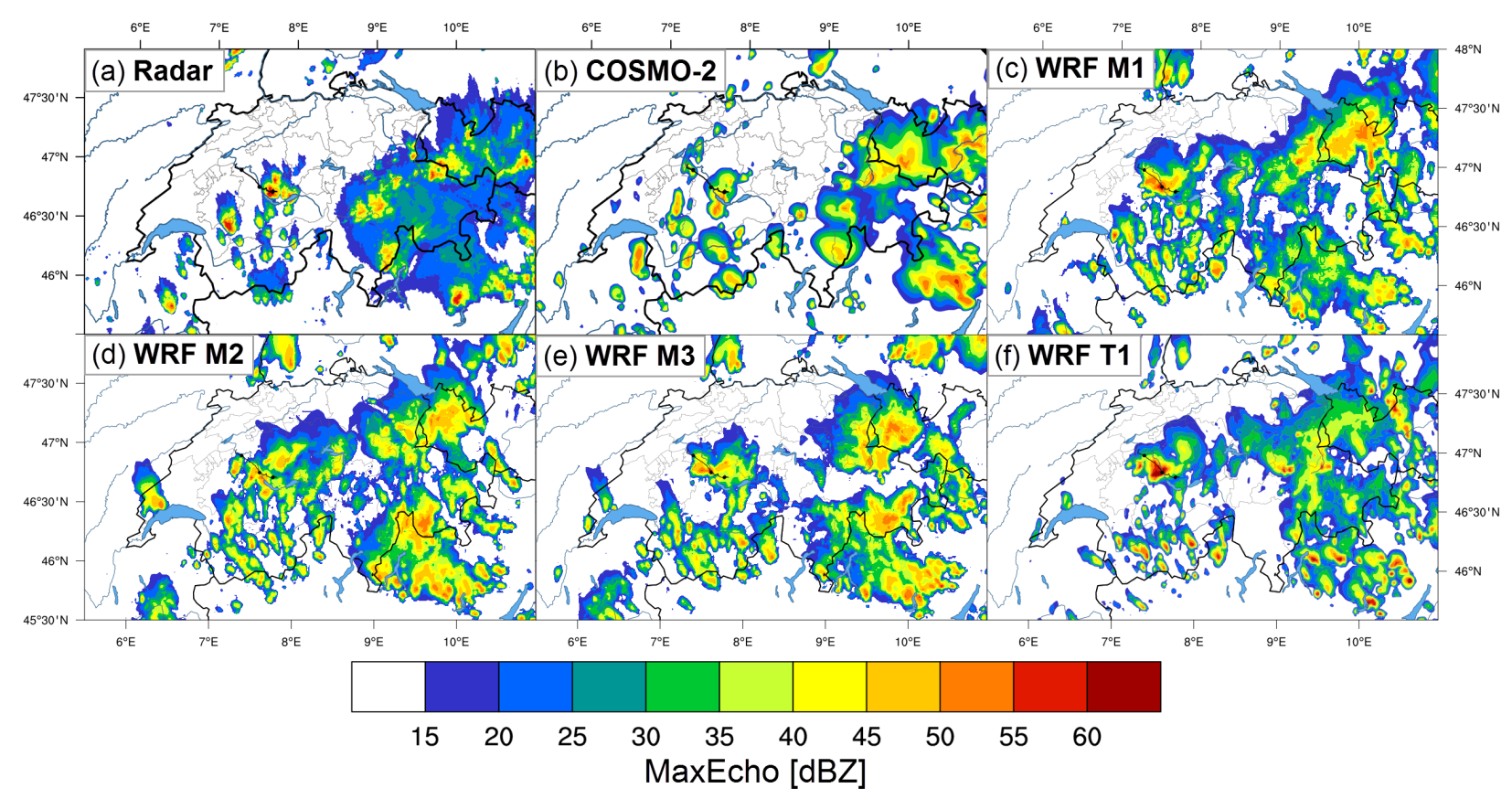

Figure 14: MaxEcho [dBZ] (a) observed by radar and simulated in (b) COSMO-2, (c) WRF M1, (d) WRF M2, (e) WRF M3 and (f) WRF T1 at 1600 UTC 6 June 2015. All figures show the observed TRT storm track (black line) and the storm position at 1600 UTC, 1700 UTC and 1800 UTC (black circle). 


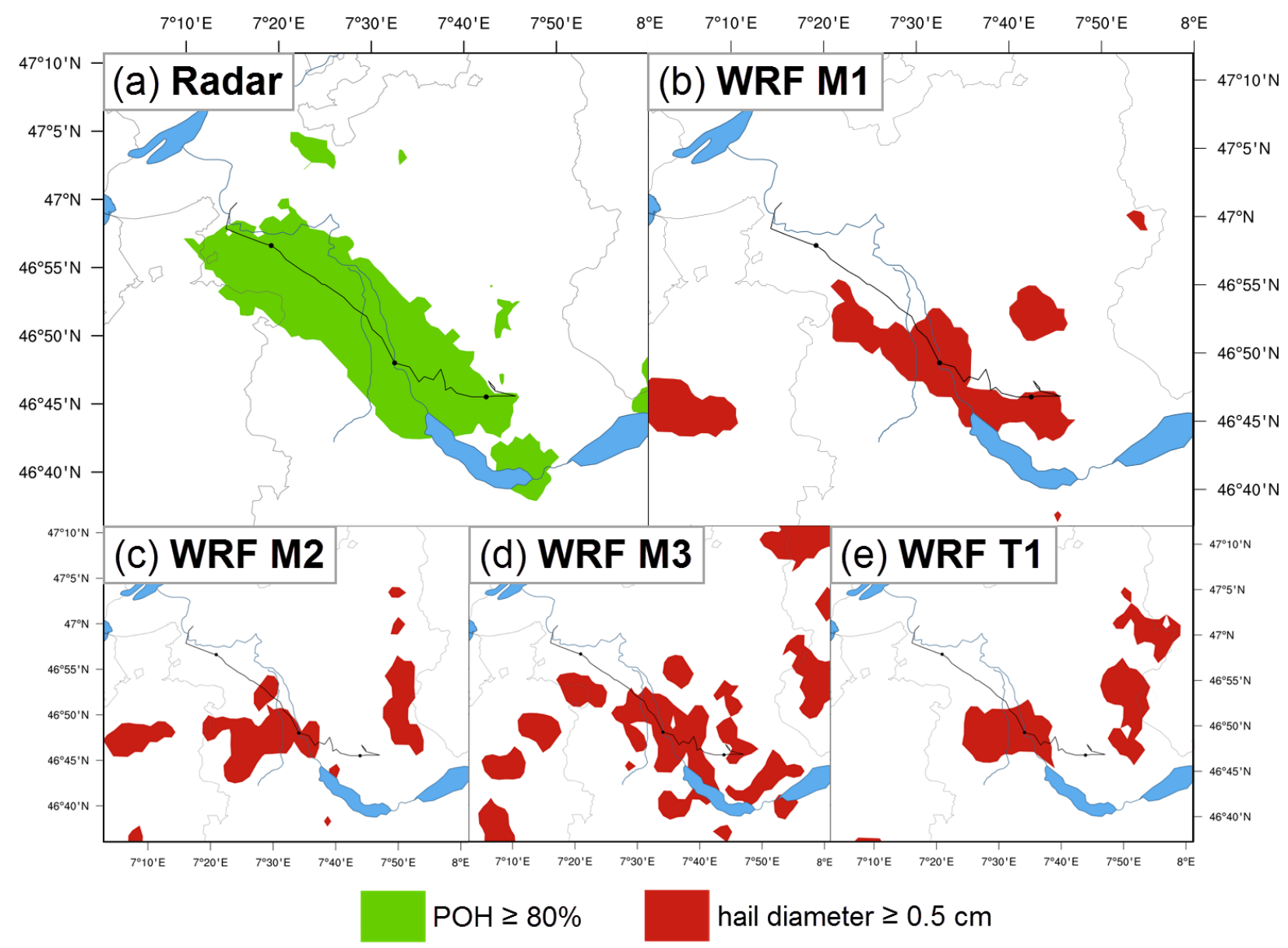

Figure 15: Hail occurrence area in the Thun-Bern region for 6 June 2015 from radar and WRF. Shown are (a) radar-derived $\mathrm{POH} \geq 80 \%$ (green), (b) hail $\geq 0.5 \mathrm{~cm}$ simulated in WRF M1, (c) WRF M2, (d) WRF M3 and (e) WRF T1. All figures show the TRT storm track (black line) and the storm position at 1600 UTC, 1700 UTC and 1800 UTC (black circle). 


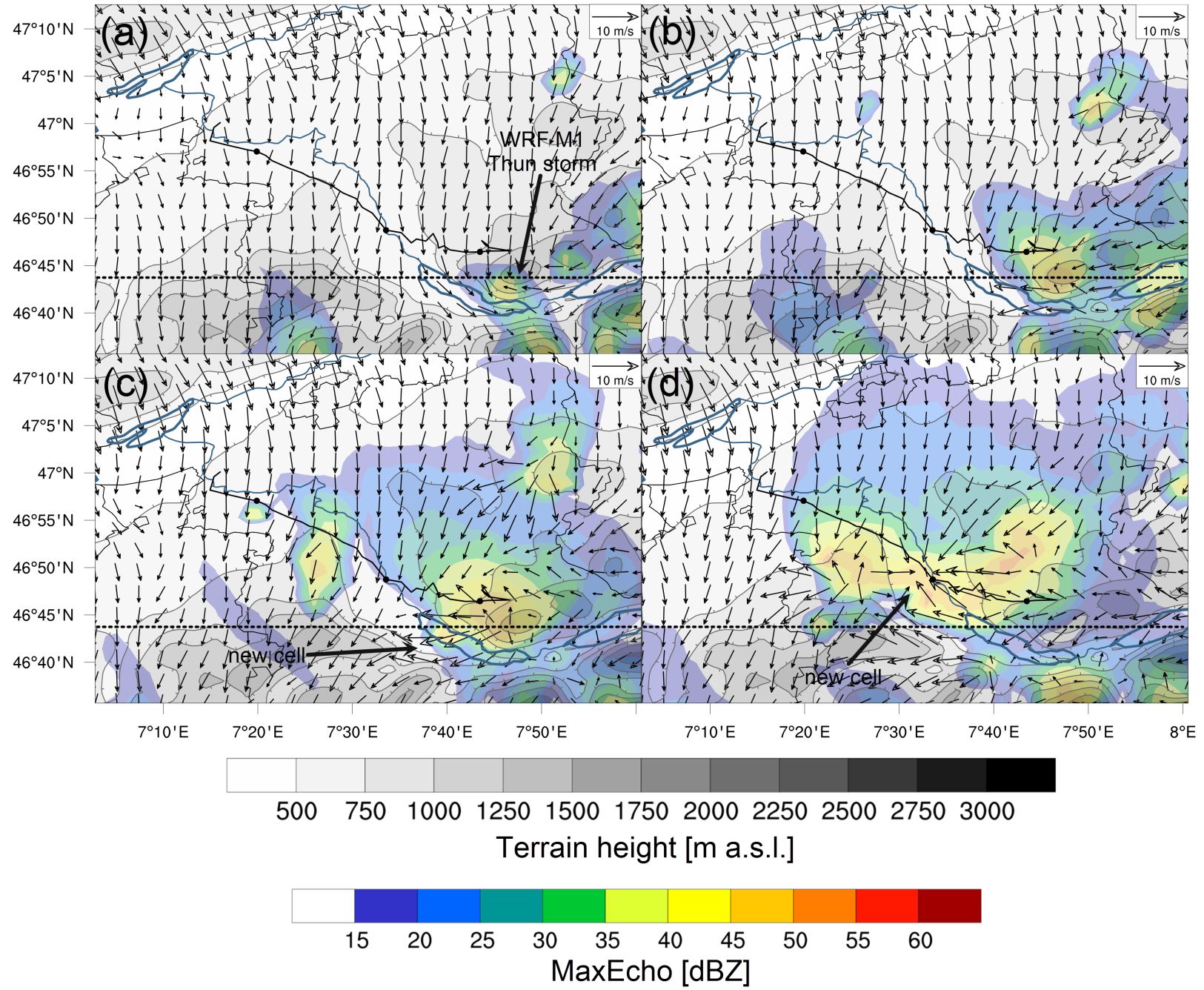

Figure 16: WRF M1 simulation MaxEcho [dBZ] and surface winds (arrows) for the Thun-Bern region (colour) over WRF model topography (grey shading) for (a) 1420 UTC, (b) 1450 UTC, (c) 1520 UTC, and (d) 1550 UTC 6 June 2015. The black dashed line indicates the zonal cross section shown in Fig. 17 The black solid line shows the observed Thun storm track and position at 1600 UTC, 1700 UTC and 1800 UTC (black circle). 

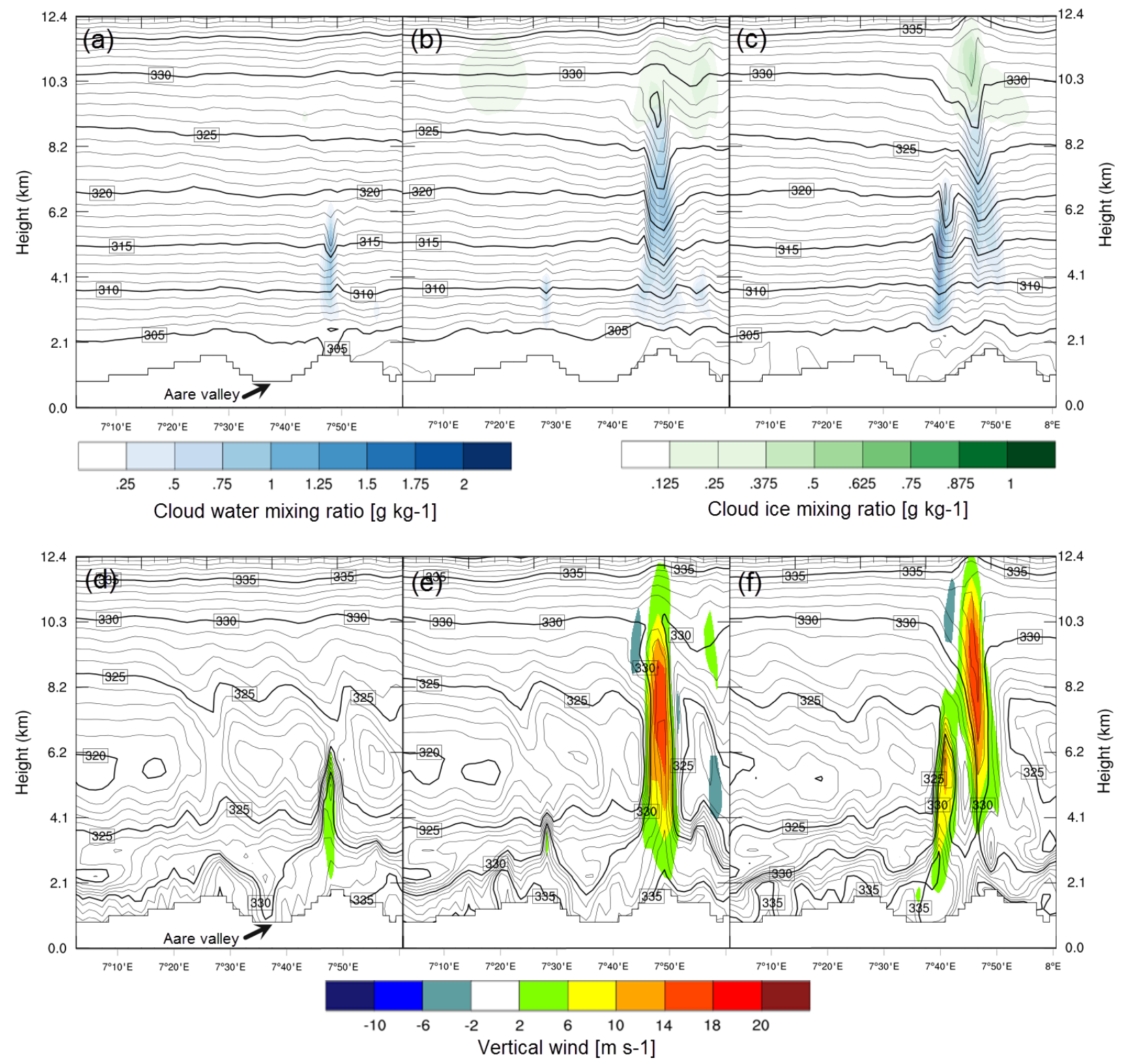

Figure 17: (a)-(c) Vertical cross sections through the WRF hail storm showing cloud water (blue) and ice (green shading) mixing ratio $\left[\mathrm{g} \mathrm{kg}^{-1}\right]$, and $\Theta[\mathrm{K}]$ (isolines) and (d)-(f) vertical wind velocity $\left[\mathrm{m} \mathrm{s}^{-1}\right]$ (shading) and $\Theta_{e}[\mathrm{~K}]$ (isolines). Times are 1420 UTC ((a) and (d)), 1450 UTC ((b) and (e)), and 1520 UTC ((c) and (f)) 6 June 2015. See location of cross section in Fig. 16 


\begin{tabular}{l|l|l|l}
\hline Class name & $\begin{array}{l}\text { Real diameter } \\
{[\mathbf{c m}]}\end{array}$ & $\begin{array}{l}\text { verified reports } \\
\text { Switzerland }\end{array}$ & $\begin{array}{l}\text { verified reports } \\
\text { Thun-Bern }\end{array}$ \\
\hline \hline Coffee bean & $0.5-0.8$ & 195 & 78 \\
\hline $\mathbf{1}$ CHF coin & 2.3 & 74 & 35 \\
\hline $\mathbf{5}$ CHF coin & 3.1 & 10 & 6 \\
\hline $\mathbf{> 5}$ CHF coin & $>3.1$ & 10 & 4 \\
\hline Total & & 289 & 123 \\
\hline
\end{tabular}

Table 1: MeteoSwiss App hailstone size class names, the corresponding diameters in $\mathrm{cm}$ and number of reports for each class after the verification with the HAILSIZE product (see text for more details) for 6 June 2015 


\begin{tabular}{l|l|ll|l|l|l|l}
\hline $\begin{array}{l}\text { Time } \\
{[\text { UTC }]}\end{array}$ & Rank [- $]$ & $\begin{array}{l}\text { VIL } \\
\left.\mathbf{m}^{-2}\right]\end{array}$ & {$[\mathrm{kg}$} & ET45 $[\mathrm{km}]$ & $\begin{array}{l}\text { MaxEcho } \\
{[\mathrm{dBZ}]}\end{array}$ & $\begin{array}{l}\text { Storm } \\
\text { area } \geq \mathbf{5 7} \\
\mathbf{d B Z}\left[\mathrm{km}^{2}\right]\end{array}$ & $\begin{array}{l}\text { Storm } \\
\text { area }\left[\mathrm{km}^{2}\right]\end{array}$ \\
\hline \hline 1700 & 38 & 58 & 10.9 & 63 & 66 & 354 \\
\hline
\end{tabular}

Table 2: Radar-based characteristics of the Thun storm at the most severe stage according to TRT severity rank (1700 UTC 6 June 2015): TRT rank, storm-area (SA) maximum VIL $\left[\mathrm{kg} \mathrm{m}^{-2}\right]$, storm-area median ET45 [km], storm-area maximum MaxEcho $[\mathrm{km}]$, storm area with echo $\geq 57 \mathrm{dBZ}\left[\mathrm{km}^{2}\right]$ and total storm area $\left[\mathrm{km}^{2}\right]$. 


\begin{tabular}{|c|c|c|c|c|c|}
\hline Storm(s) & $\begin{array}{l}\text { ET15 } \\
{[\mathrm{km}]}\end{array}$ & $\begin{array}{l}\text { ET45 } \\
{[\mathrm{km}]}\end{array}$ & $\begin{array}{ll}\text { VIL } & {[\mathrm{kg}} \\
\left.\mathbf{m}^{-2}\right] & \end{array}$ & $\begin{array}{l}\text { Storm } \\
\text { area } \\
{\left[\mathrm{km}^{2}\right]}\end{array}$ & $\begin{array}{l}\text { Mean ve- } \\
\text { locity [km } \\
\left.\mathbf{h}^{-1}\right]\end{array}$ \\
\hline Thun storm & 13.6 & 10.9 & 58 & 495 & 6.02 \\
\hline Other severe cells & $13.6-17.6$ & $9.7-13.2$ & $56-80.5$ & $464-765$ & $4.5-18.6$ \\
\hline
\end{tabular}

Table 3: Comparison of radar-derived storm lifetime maxima of storm-area median ET15 [km], storm-area median ET45 [km], storm-area maximum VIL $\left[\mathrm{kg} \mathrm{m}^{-2}\right]$, storm area $\left[\mathrm{km}^{2}\right]$ and the mean storm propagation velocity $\left[\mathrm{km} \mathrm{h}^{-1}\right]$ for the Thun storm versus a set of 11 other storms with at least the same length of 'very severe' TRT severity classification (55 min). 